\title{
Investigation of groundwater-surface water interaction using hydrochemical sampling with high temporal resolution, Mangatarere catchment, New Zealand
}

M. R. Guggenmos ${ }^{1}$, B. M. Jackson ${ }^{1}$, and C. J. Daughney ${ }^{2}$

${ }^{1}$ School of Geography, Environment and Earth Sciences, Victoria University of Wellington, Wellington, New Zealand

${ }^{2}$ GNS Science, Lower Hutt, New Zealand

Received: 5 October 2011 - Accepted: 15 October 2011 - Published: 21 November 2011 Correspondence to: M. R. Guggenmos (michael.guggenmos@urs.com)

Published by Copernicus Publications on behalf of the European Geosciences Union.
Investigation of groundwater-surface water interaction

\section{R. Guggenmos et al.}

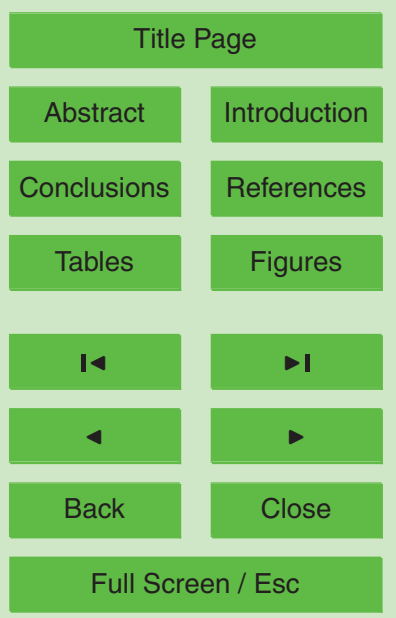

Printer-friendly Version

Interactive Discussion 


\section{Abstract}

The interaction between groundwater and surface water is dynamic and is known to show considerable spatial and temporal variability. Generally hydrological studies that investigate this interaction are conducted at weekly to yearly timescales and inad5 vertently lose information contained at the neglected shorter timescales. This paper utilises high resolution physical and chemical measurements to investigate the groundwater and surface water interactions of the small temperate Mangatarere Stream in New Zealand. Continuous electrical conductivity, water temperature and stage measurements were obtained at two surface water gauging stations and one groundwater the along with one week of intensive hydrochemical grab sampling. A second groundwater gauging station provided limited additional data. The downstream reach of the Mangatarere Stream received significant base flow from neighbouring groundwaters which provided cool $\mathrm{Na}^{+}-\mathrm{Cl}^{-}$type waters, high in TDS and $\mathrm{NO}_{3}^{-}$concentrations. This reach also lost water to underlying groundwaters during an extended dry period 15 when precipitation and regional groundwater stage were low. The upstream groundwater station received recharge primarily from precipitation as indicated by a $\mathrm{Na}^{+}$$\mathrm{Cl}^{-}-\mathrm{NO}_{3}^{-}$signature, the result of precipitation passage through the soil-water zone. However, river recharge was also provided to the upstream groundwater station as indicated by the transferral of a diurnal water temperature pattern and dilute $\mathrm{Na}^{+}-\mathrm{Ca}^{2+}$. $\mathrm{Mg}^{2+}-\mathrm{HCO}_{3}^{-}-\mathrm{Cl}^{-}$signature. Results obtained from the Mangatarere catchment confirm the temporal complexities of groundwater and surface water interaction and highlight the benefits of multiple investigative approaches and the importance of high frequency hydrochemical sampling and monitoring for process understanding.

\section{Introduction}

25 The interaction between surface water and groundwater is dynamic and is known to show considerable spatial and temporal variability. Quantification and understanding
HESSD

8, 10225-10273, 2011

\section{Investigation of groundwater-surface water interaction}

\section{R. Guggenmos et al.}

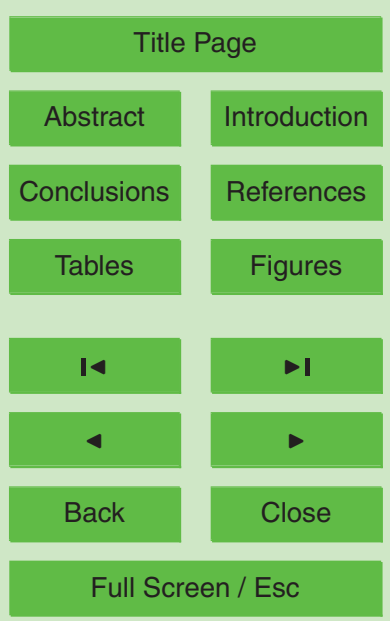

Printer-friendly Version

Interactive Discussion 
of this interaction is extremely important for determining safe levels of groundwater allocation and environmental river flows, identifying transportation of contaminants across the stream-aquifer boundary and managing in-stream ecology (Cook et al., 2003). Increasingly, interdisciplinary investigations have sought to understand the linkage be5 tween groundwater and surface water and the range of geomorphic, anthropogenic and meteorological processes that influence it (Brunke and Gonser, 1997; Rodgers et al., 2004).

Common approaches employed in the investigation of groundwater and surface water interaction include quantification of changes in water stage and discharge, water 10 temperature, chemical tracers and/or hydrograph separation (Sophocleous, 2002). Although these methods each have their own benefits and limitations, it is generally accepted that a multi-method approach, in which various methods are combined, provides the most accurate picture of interaction with the greatest levels of certainty (Kalbus et al., 2006). This paper primarily focuses on the use of chemical tracers 15 to investigate surface water and groundwater interactions, but supplements these with physically based methods (i.e. water temperature and stage quantification). By monitoring similarities and differences in tracer behavior, one can gain insight into the relative importance of different catchment water sources and the potential interaction between chemically distinct groundwater and surface water bodies (Tetzlaff and Soulsby, 2008). Numerous studies suggest that similarities in water composition, total dissolved solids, nutrient concentrations and ion ratios between neighboring groundwater and surface water bodies can also be used to infer potential stream-aquifer interaction (e.g. Burden, 1982; Taylor et al., 1989; Kumar et al., 2009). Groundwaters that provide base flow to surface water systems generally elevate surface water TDS and transfer their chemical signature (typically $\mathrm{Na}-\mathrm{Cl}-\mathrm{NO}_{3}$ ) to overlying fluvial systems (e.g. Taylor et al., 1989; Rozemeijer and Broers, 2007). Furthermore, groundwater systems that receive a significant proportion of recharge from river systems have been found to display a relatively dilute $\mathrm{Ca}-\mathrm{HCO}_{3}$ chemical signature typical of global fresh water river systems dominated by carbonate dissolution (e.g. Burden et al., 1982; Berner
HESSD

8, 10225-10273, 2011

\section{Investigation of groundwater-surface water interaction}

M. R. Guggenmos et al.

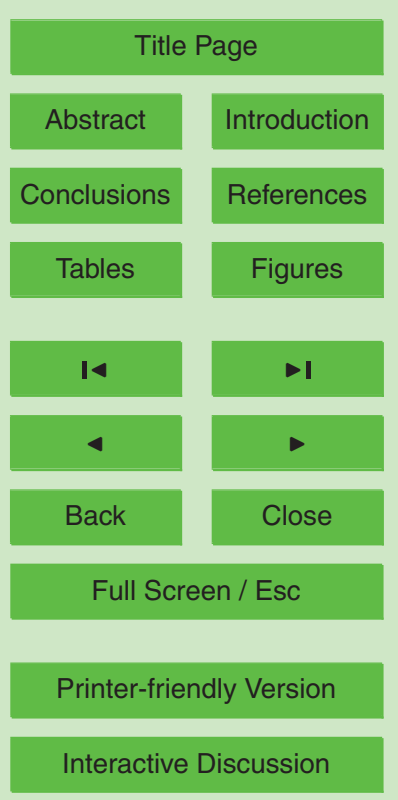


and Berner, 1996; Güler and Thyne, 2004; Guggenmos et al., 2011). Generally hydrological investigations and chemical monitoring of groundwater and surface water bodies are conducted at weekly to yearly timescales (e.g. Scanlon, 1989; Bjerg and Christensen, 1991; Hill and Neal, 1997; Wollsclager et al., 2007), as one off samples 5 (e.g. Taylor et al., 1989) and/or during individual storm events (e.g. Rodgers et al., 2003). These temporal regimes are largely determined by monetary restrictions and the common perception that significant hydrological and chemical responses do not occur during base flow conditions (Kirchner et al., 2004; Kirchner, 2006; Tetzlaff and Soulsby, 2008). Although these temporal resolutions may arguably be sufficient for 10 many operational hydrology purposes, they fail to progress our understanding of hydrological systems and their associated processes as they inadvertently lose information contained at the shorter neglected (unmeasured) temporal timescales (Kirchner, 2006). Catchments are known to respond hydrologically and chemically on timescales of minutes to hours (Kirchner, 2006). Significant transfer of water across the stream15 aquifer boundary can occur within seconds, with exchange areas that are often small and easily missed (USEPA, 2000).

This highlights the importance of identifying groundwater and surface water interactions occurring at sub-weekly and sub-daily timescales and the potential influence this may have on the chemical composition of water bodies. Further, works by Kirchner et 20 al. (2004), Schmalz et al. (2007) and Piak et al. (2008) suggest that significant hydrochemical changes in stream flow, potentially caused by the interaction between surface water and groundwater bodies, are easily missed by weekly and monthly monitoring. There is still much to be learned about the interaction between groundwater and surface water bodies, in particular the temporal scale at which this interaction occurs and the subsequent impact on the chemical composition of water bodies involved. New high resolution chemical datasets are required from a range of diverse climatic and geomorphic environments, as well as environments likely to be affected by changing landuse and climate scenarios. Results presented in this paper are the latter part of an investigation into regional surface and groundwater interaction in the Wairarapa Valley
HESSD

8, 10225-10273, 2011

\section{Investigation of groundwater-surface water interaction}

M. R. Guggenmos et al.

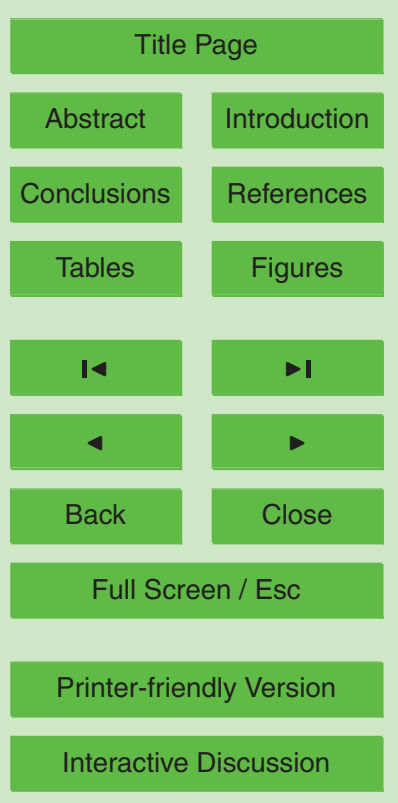


of New Zealand. Initial investigations presented in Guggenmos et al. (2011) utilized multivariate statistical methods and site specific hydrochemical medians from regional datasets to group surface water and groundwater bodies, based on similarities in hydrochemistry, to infer interaction between them. These preliminary investigations used 5 site specific median values that fail to acknowledge temporal variability in water quality and therefore neglect temporal aspects of surface water and groundwater interaction. Such datasets do however present a starting means by which areas that show some indications of potential interaction between surface and groundwater bodies can be identified for further research.

10 Results indicated spatially disparate coupling between surface water and groundwater bodies at both local and regional scales and highlighted a limited number of areas as being of particular interest. One such area was the Mangatarere stream, which displayed a similar $\mathrm{Na}-\mathrm{Cl}-\mathrm{NO}_{3}$ signature to that of neighboring rainfall-recharged groundwaters. This strongly suggests that the Mangatarere stream receives a significant input from underlying groundwater systems.

Therefore, the objective of the research described in this paper was to investigate surface water and groundwater interactions in the small temperate Mangatarere catchment in New Zealand using new field derived high frequency hydrological and chemical data. These data were used to assess high frequency temporal changes in hydrochemical, fluvial and meteorological processes from an upper and lower reach of the Mangatarere stream during the summer of 2009-2010 in order to quantify and understand the relative transfer of water across the Mangatarere's stream-aquifer interface over this period. Both physical and chemical data were collected in order to reduce the uncertainties associated with individual methods and hence increase our understanding
HESSD

8, 10225-10273, 2011

\section{Investigation of groundwater-surface water interaction}

M. R. Guggenmos et al.

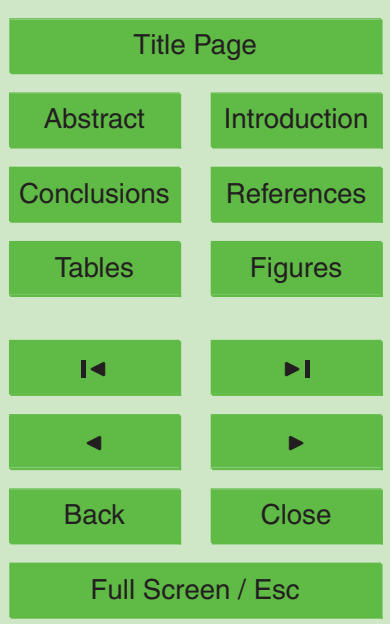

Printer-friendly Version

Interactive Discussion 


\section{Field site description}

The Mangatarere stream catchment is located within the Wairarapa Valley, a $90 \mathrm{~km}$ long structural depression in the south-east corner of the North Island of New Zealand (Fig. 1) (McConchie, 2000). Catchment headwaters originate in the low altitude (3005600 m.a.s.l) Tararua Ranges and are comprized of Torlesse greywacke, overlain by a composite of mudstone, basalt and limestone (Fig. 2a) (Kamp, 1992). The southeastern section of the catchment is comprised of moderately sorted Quaternary alluvial gravels (>10 ka) with minor sand and silt underlying terraces (Morgan and Hughes, 2001). These sedimentary layers are the result of various depositional periods and historic flood events. The catchment is dissected by the northeast trending Masterton, Wairarapa and Carterton fault lines that have resulted in the uplift of low permeability middle Quaternary sediment layers to the surface (Fig. 2a).

Precipitation in the catchment is highly influenced by the Tararua Ranges, which act as a topographic barrier, sheltering the lower catchment from the predominantly 15 westerly winds. The highest mean annual precipitation is experienced in the ranges $(2400-6000 \mathrm{~mm})$ while the catchment floor receives $800-1200 \mathrm{~mm} \mathrm{yr}^{-1}$. The majority of this precipitation generally falls during the winter months (July-August), however precipitation is more variable during the summer. Mean annual air temperature is approximately $12-14{ }^{\circ} \mathrm{C}$ for the Wairarapa Valley and it is common for dry fohn winds to move across the valley during the summer months. Mean monthly temperature during the summer is $12-24^{\circ} \mathrm{C}$ (Hawke, 2000).

The Mangatarere catchment is home to several creek and stream systems, the largest being the Mangatarere stream that originates in the Tararua Ranges (Fig. 2b). Runoff to the Mangatarere stream is primarily sourced from precipitation, small tributary creeks and groundwater inputs as it flows through ca. $8 \mathrm{~km}$ of the Mangatarere Valley in the Tararua Ranges. The headwaters of the stream are relatively unconfined, however the stream has incised a permanent passage as it meanders through the Mangatarere Valley. Surrounding landuse in the upper valley is low intensity agriculture and

HESSD

8, 10225-10273, 2011

\section{Investigation of groundwater-surface water interaction}

M. R. Guggenmos et al.

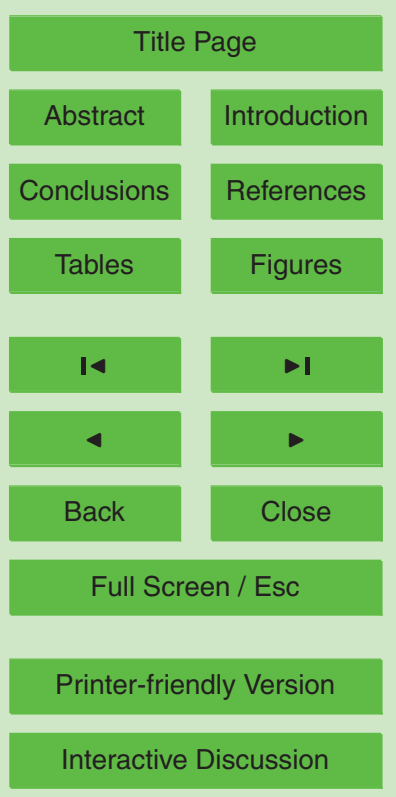

Interactive Discussion 
native bush (Fig. 2a). After exiting the valley the stream is primarily sinuous and moves southwest across the western alluvial fans of the larger Wairarapa Valley before joining with the Waiohine River. Sediment directly below the stream largely consists of well sorted river gravels $(>10 \mathrm{ka})$, however high flow events have resulted in the hap5 hazard deposition of larger rocks $(30-50 \mathrm{~cm})$ on the stream bed. A number of minor fluvial systems such as Beef Creek, Kaipatangata and Enaki streams provide waters to the Mangatarere along this ca. $15 \mathrm{~km}$ section (Fig. 2b). Approximate catchment areas and discharge ranges for these streams are presented in Table 1. The Mangatarere's flow displays a strong seasonal pattern with flow generally highest during the winter 10 months of June to August $\left(2-3 \mathrm{~m}^{3} \mathrm{~s}^{-1}\right)$ and lowest during the drier summer months of December to February $\left(0.9-1.4 \mathrm{~m}^{3} \mathrm{~s}^{-1}\right)$. This flow pattern is principally governed by local precipitation, of which the greatest quantities are experienced in the region during the winter. The stream is known to interact with underlying groundwater systems as indicated by a range of flow measurements undertaken by the Greater Wellington 15 Regional Council (GWRC) (Jones and Gyopari, 2006). It is assumed the stream loses flow to underlying groundwaters as it moves through the Mangatarere Valley, a trend that continues along its middle reaches. This system of interaction switches as the Mangatarere passes over the Carterton fault line and groundwaters provide a proportion of base flow to the stream. As a result of this input from tributary streams and groundwater sources, flow is greatest in the lower reaches of the stream.

Groundwaters in the Mangatarere catchment primarily flow in a south-easterly direction away from the Tararua Ranges (Fig. 2a). These groundwaters are part of the larger Carterton sub-regional flow system with boundaries set by the Wairarapa fault to the west. Recharge is provided to the Carterton flow system by both river and rainfall 25 recharge mechanisms and utilized unconfined shallow aquifers exist at 5-15 $\mathrm{m}$ deep (Morgan and Hughes, 2001). Shallow aquifer through-flow below the Mangatarere is estimated by the GWRC at 7.6 million $\mathrm{m}^{3} \mathrm{yr}^{-1}$ (Morgan and Hughes, 2001). In the middle reaches of the Mangatarere, after the stream exits the Tararua Ranges, flow is lost to the underlying groundwater system. Direct recharge from precipitation becomes
HESSD

8, 10225-10273, 2011

\section{Investigation of groundwater-surface water interaction}

M. R. Guggenmos et al.

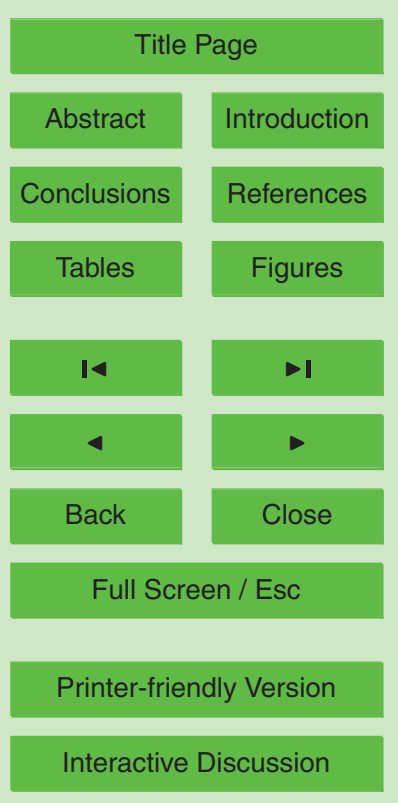


increasingly important as the distance from the Mangatarere increases. Darcy flow calculations indicate potential horizontal groundwater flow between 6-10 m per day (Guggenmos, 2010).

The Mangatarere catchment is largely dominated by native bush, shrub lands and 5 agriculture on the valley flat (Fig. 1b). As the river exits the Tararua Ranges, landuse is almost entirely medium intensity agriculture, with the small township of Carterton (population ca. 4014) located 500-900 m east of the stream on the Wairarapa Valley flat. A high intensity pig farm (10000 sows) is also located ca. $200 \mathrm{~m}$ from the stream in its middle reaches. This operation sprays up to $200000 \mathrm{~m}^{3} \mathrm{yr}^{-1}$ of effluent on neighboring 10 paddocks. Treated sewage from the township of Carterton is also discharged into the Mangatarere stream (ca. $285000-500000 \mathrm{~m}^{3} \mathrm{yr}^{-1}$ ).

\section{Field and laboratory methods}

The summer field programme reported here was conducted between the 20 November 2009 and the 20 February 2010 (Julian Day-JD-324-051). This period of study 15 was chosen due to the variability of precipitation experienced in the Wairarapa Valley during the summer months - generally presenting both extended dry periods and intense precipitation events. Previous regional scale hydrological and hydrochemical investigations had suggested contrasting mechanisms of surface water and groundwater interaction on the Mangatarere stream, with the upstream reaches thought to provide recharge to underlying groundwaters while the downstream reaches received base flow largely from groundwater sources (Jones and Gyopari, 2006; Guggenmos et al., 2011). As a result, contrasting upstream and downstream monitoring areas were established to investigate surface water and groundwater interaction on both a losing (upstream) and gaining (downstream) reach of the Mangatarere stream. Each gaug-

ing area consisted of a surface water and groundwater gauging station, the location of which was determined by (1) landowner approval; (2) the presence of an existing and currently operational groundwater bore; and (3) a stable river cross section. The

HESSD

8, 10225-10273, 2011

\section{Investigation of groundwater-surface water interaction}

\section{R. Guggenmos et al.}

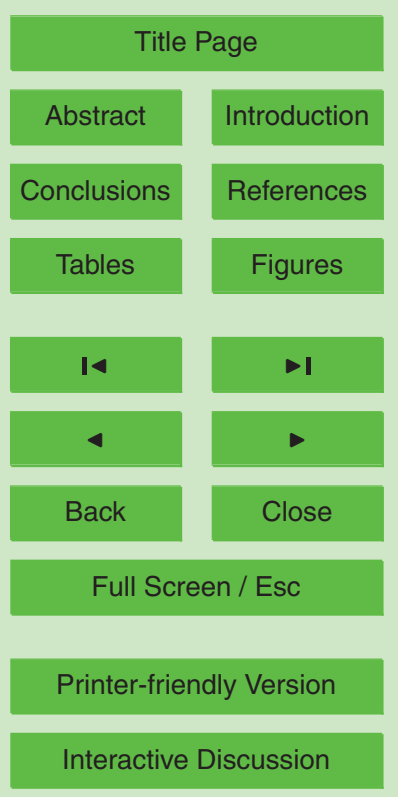


upstream monitoring stations were located in the middle reaches of the Mangatarere, where the stream exits the Tararua Ranges across a historic alluvial fan. Surrounding landuse is largely agricultural (dairy and high intensity pig farming), with the $10 \mathrm{~m}$ deep groundwater monitoring bore used primarily for water quality monitoring. The strati5 graphic makeup of the upstream groundwater site consists of a mixture of clay bound gravels, rock, sand and free sandy gravels. Top soil is present to a depth of ca. $50 \mathrm{~cm}$. The neighboring surface water gauging station is located ca. $300 \mathrm{~m}$ south-east on the banks of the Mangatarere Stream.

The lower gauging stations were located ca. $10 \mathrm{~km}$ downstream and utilized an ex10 isting 6 meter deep groundwater bore located ca. $35 \mathrm{~m}$ from the Mangatarere stream. The bore is not in current use. The neighboring surface water monitoring station was located ca. $300 \mathrm{~m}$ south-west and utilizes an existing downstream gauging station installed and operated by GWRC. The downstream surface water gauging station has a ca. $130 \mathrm{~km}^{2}$ catchment area that includes the upstream surface water catchment 15 (ca. $52 \mathrm{~km}^{2}$ ) and inputs from Enaki and Kaipatangata streams (ca. 32 and $23 \mathrm{~km}^{2}$ catchments respectively - Table 1). Both upstream and downstream groundwater monitoring wells are not used for water abstraction and therefore were deemed likely to display a natural behavior.

In order to assess potential changes in the physical and chemical properties of sur20 face and groundwater bodies and infer interaction based on these changes, water stage, temperature and electrical conductivity were measured continuously at all four gauging stations from the 20 November 2009 until the 20 February 2010 (JD324-051). These parameters were chosen as they can be recorded using relatively cheap, real time sensors and they provide information on both the physical and chemical state of water bodies. Water stage measurements were obtained with miniTROLL SSP-100 absolute pressure transducers, while temperature and conductivity were collected by Campbell Scientific CS547A probes (range $0.5-700 \mu \mathrm{S} \mathrm{cm}^{-1}$, accuracy $\pm 18 \mu \mathrm{S} \mathrm{cm}^{-1}$ ) and logged in Campbell Scientific 10X dataloggers. Prior to installation, each CS547A probe was laboratory calibrated for accuracy using a $180 \mu \mathrm{S}$ salt solution and again
HESSD

8, 10225-10273, 2011

\section{Investigation of groundwater-surface water interaction}

M. R. Guggenmos et al.

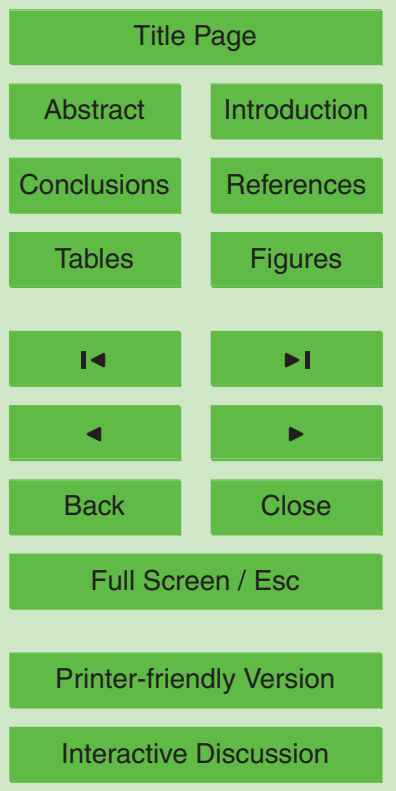

10233 
upon removal to identify potential measurement drift. Conductivity data were automatically adjusted to a common temperature of $25^{\circ} \mathrm{C}$ as is common in the hydrochemical literature (e.g. Jagannadha Sarma et al., 1979; Laudon and Slaymaker, 1997) and displayed $a \pm 10 \%$ level of accuracy. Each SSP-100 pressure transducer was field 5 calibrated using a manual bore dipper and found to be accurate $\pm 1 \mathrm{~cm}$, consistent with values provided by the manufacturer for 0-11 $\mathrm{m}$ water level ranges. Surface water probes were installed within the thalweg of the Mangatarere, while groundwater probes were installed at a depth of $6.5 \mathrm{~m}$ (upstream) and $4.5 \mathrm{~m}$ (downstream) from the top of the bore casing. These installation depths are the approximate middle depth of each 10 groundwater column and provided security against sudden changes in water depth and contamination from the aquifer base.

All water temperature, water stage and conductivity measurements were recorded at 15 min intervals with the exception of downstream surface water conductivity which was operated by GWRC and, due to a lack of datalogger storage space, had measurements obtained at hourly intervals. Although probes were installed at the downstream groundwater gauging station, technical problems in regards to power supply resulted in the loss of all data from this site. An erratic power supply also resulted in the loss of data from the downstream surface water gauging station during the period JD324-346 and JD360-012.

Continuous air temperature measurements were obtained from the upstream surface water gauging station using a Campbell Scientific 109-L temperature sensor $\left( \pm 0.2^{\circ} \mathrm{C}\right.$ accuracy) and assumed applicable to both gauging areas due to their close proximity. Precipitation data were sourced from a neighboring pig farm located between the two monitoring areas using a Vaisala Weather Transmitter WXT520 $( \pm 0.5 \mathrm{~mm}$ accuracy).

25 An erratic recording interval in the WXT520's programming resulted in precipitation measurements being presented as daily totals $\left(\mathrm{mm} \mathrm{day}^{-1}\right)$.
HESSD

8, 10225-10273, 2011

\section{Investigation of groundwater-surface water interaction}

M. R. Guggenmos et al.

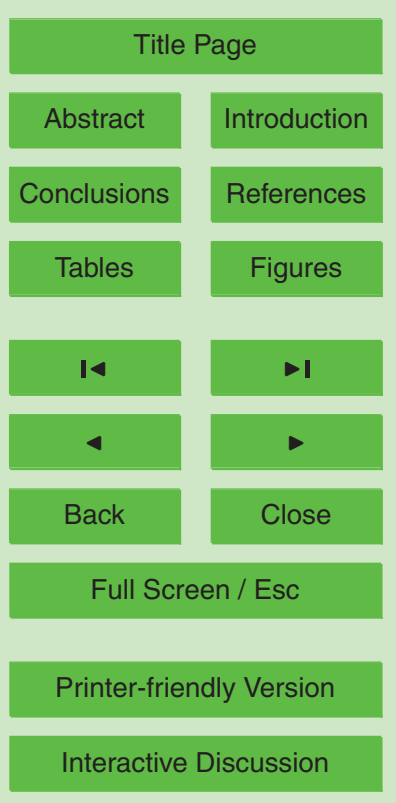




\subsection{Hydrochemical grab sampling}

A one week intensive hydrochemical sampling programme was conducted during the period JD021 to JD028. Sampling was specifically undertaken during this period because significant precipitation was forecast after a dry spell. This strategy resulted 5 from a perception that such conditions would likely stimulate change in hydrochemistry in both the surface water and groundwater systems. The sampling scheme consisted of 48 sampling events, conducted at the upstream and downstream surface water and groundwater gauging sites. The downstream groundwater site was minimally sampled because equipment failure prevented any grab sample data being put in the context the high resolution monitoring. Therefore, in order to reduce sampling costs, we selectively sampled this site three times (JD021, JD023 and JD028 in 2010) during the sampling period. Six days (JD021-024 and 027-028) of once daily sampling were conducted at the three remaining sites in order to investigate daily changes in water chemistry. This was supplemented with an additional $24 \mathrm{~h}$ period of three hour 15 interval sampling (from 12:00 h JD025 till 12:00 h JD026) in order to investigate diurnal changes. In addition, two rainfall samples were collected on JD022 and JD027 to ascertain any additional chemical inputs from precipitation.

During each sampling event, the sampling procedure included the collection of three individual water samples: a $100 \mathrm{ml}$ field filtered, un-preserved sample for the analysis of major anions; a $100 \mathrm{ml}$ field filtered, high purity nitric acid preserved sample for the analysis of major cations, total ammoniacal nitrogen $\left(\mathrm{NH}_{4}\right)$ and reactive phosphorous $(\mathrm{P})$; and a 11 un-filtered, un-preserved sample for the analysis of other nutrients and alkalinity. Groundwater bores were purged for several minutes prior to sampling to remove ca. three casings of stagnant water and to prevent contamination between sites filters and all filtered and preserved samples were treated with $2 \mathrm{ml}$ of high purity nitric acid. All samples were stored in acid cleaned, sample rinsed, polyethylene bottles, refrigerated to $4^{\circ} \mathrm{C}$ and analysed within $24 \mathrm{~h}$.

HESSD

8, 10225-10273, 2011

\section{Investigation of groundwater-surface water interaction}

M. R. Guggenmos et al.

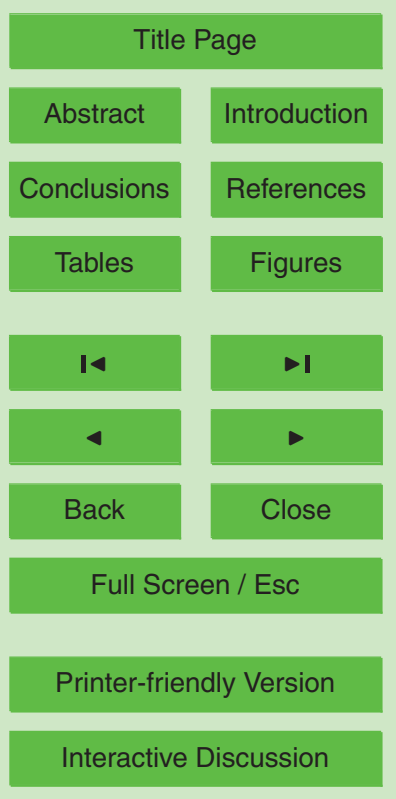


All analyses were conducted by Hill Laboratories Ltd in Hamilton, New Zealand using standard industry methods. The concentrations of $\mathrm{Ca}, \mathrm{Mg}, \mathrm{K}, \mathrm{Na}, \mathrm{Mn}$ and $\mathrm{Fe}$ were determined by inductively coupled plasma mass spectrometer with an associated 6-10\% level of accuracy. Concentrations of $\mathrm{Cl}^{-}$and $\mathrm{SO}_{4}{ }^{2+}$ were determined by Fer5 ric thiocyanate colorimetry and ion chromatography respectively while the $\mathrm{NH}_{4}-\mathrm{N}$ and dissolved reactive phosphorous were quantified by discrete analysis using the Phenol/hypochlorite and Molybdenum blue colorimetry methods respectively. The nutrients $\mathrm{NO}_{3}-\mathrm{N}$ and $\mathrm{NO}_{2}$ were determined through flow injection analysis, automated cadmium reduction and Azo dye colorimetry. Concentrations of total alkalinity were determined 10 using an autotitrator with acid free water samples lowered to a $\mathrm{pH}$ of 4.5 (M-alkalinity), with subsequent results used in the calculation of $\mathrm{HCO}_{3}^{-}$concentrations. Total dissolved solids (TDS) were determined by the summation of major cations ( $\mathrm{Ca}, \mathrm{Na}, \mathrm{K}$, $\mathrm{Mg})$ and anions $\left(\mathrm{Cl}^{-}, \mathrm{SO}_{4}{ }^{2-}, \mathrm{HCO}_{3}^{-}\right)$.

\section{Results and discussion}

\section{4.1 Catchment hydrology}

Continuous monitoring of electrical conductivity, water stage and water temperature was carried out from JD324-051 at all four gauging stations. As discussed previously, equipment failure resulted in the loss of all data at the downstream groundwater station, while data gaps are present in the downstream surface water station due to an erratic power supply. Full 15 min gauging records were obtained from the two upstream gauging stations. All existing data are presented alongside precipitation in Fig. 3. Precipitation occurred during 39 days of the 94 day study period with significant events (>20 mm day ${ }^{-1}$ ) experienced on JD332, 335, 346, 022,023 and 027. These events all coincided with stage increases at both surface water gauging stations JD335, 346 and 022-023 (Fig. 3). Groundwater stage increases displayed a gradual

HESSD

8, 10225-10273, 2011

\section{Investigation of groundwater-surface water interaction}

\section{R. Guggenmos et al.}

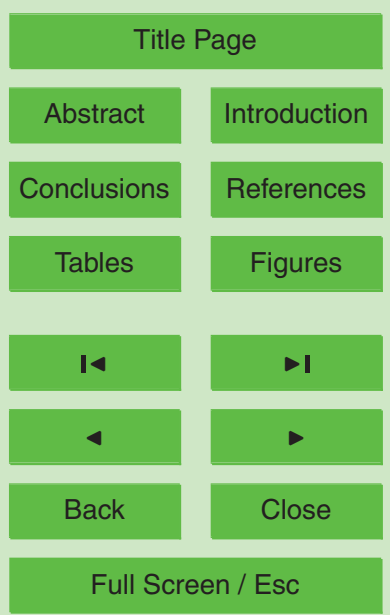

Printer-friendly Version

Interactive Discussion 
rising limb suggesting infiltrating waters took several days to percolate and/or to move new water and older waters from the vadose zone to the water table (Dahan et al., 2008; Lu et al., 2010). Dry periods, in which little or no precipitation was experienced ( $<10 \mathrm{~mm}_{\text {week }}{ }^{-1}$ ), occurred during JD324-332, 337-345, 347-365 and 0345 044. These dry periods, along with summer temperatures and subsequent increased evaporative capacity, are likely to have reduced soil moisture conditions allowing increased infiltration of precipitation and a lack of hydrological stream or groundwater response. January 2010 (JD001-031) was the wettest $(225 \mathrm{~mm})$ of the three months in which monitoring was undertaken.

10 Clear differences in river stage are present between the upstream and downstream gauging stations with downstream stage generally $10 \mathrm{~cm}$ higher for the majority of the study period (Fig. 3). This stage difference in combination with a larger cross sectional area at the downstream surface water station suggests increased flow at the downstream gauging station and is consistent with the larger downstream catchment area

15 (ca. $130 \mathrm{~km}^{2}$ including the ca. $53 \mathrm{~km}^{2}$ upstream gauging station catchment) and the assumption of possible groundwaters influxes to the downstream surface water site. This surface water stage difference increased to ca. $20 \mathrm{~cm}$ following the storm event experienced on JD021-024 as the downstream receding flood limb responded to precipitation on JD027 and therefore required more time to return to base flow conditions

20 (Fig. 3). The extension of this receding limb is likely the result of delayed inputs of precipitation, subsurface and overland flow waters from within the larger downstream catchment (Jenkins et al., 1994).

\subsection{Catchment hydrochemical response}

Figure 3 shows the temporal variability of electrical conductivity (EC) from the upstream 25 surface water and groundwater gauging stations and the downstream surface water gauging station. EC at the upstream and downstream surface water sites followed a similar pattern and experienced numerous dilution events in response to surface water stage increases. In general, downstream surface EC (ca. $100-110 \mu \mathrm{S} \mathrm{cm}^{-1}$ )
HESSD

8, 10225-10273, 2011

\section{Investigation of groundwater-surface water interaction}

M. R. Guggenmos et al.

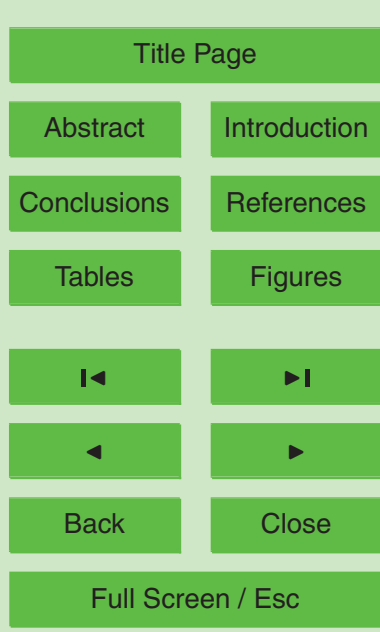

Printer-friendly Version

Interactive Discussion 
was higher than that experienced upstream (ca. $80 \mu \mathrm{S} \mathrm{cm}^{-1}$ ), indicating that a higher proportion of downstream flow is provided by solute rich, older groundwaters. Following dilution events, downstream surface water EC tends to return to base conditions faster than upstream, suggesting that the majority of runoff following the initial peak flow is 5 provided by a groundwater base flow component (Oxtobee and Navakowski, 2002).

Upstream and downstream groundwaters displayed higher concentrations of TDS and major ions in comparison to the surface water gauging stations (Table 2). This reflects higher rock:water contact periods and dissolution of minerals (Chebotarev, 1955). Concentrations of the nutrients $\mathrm{NO}_{3}-\mathrm{N}, \mathrm{NH}_{4}-\mathrm{N}$ and $\mathrm{P}$ were relatively low at the upstream surface water station $\left(0.04,0.01\right.$ and $0.006 \mathrm{mg} \mathrm{I}^{-1}$ respectively), while high concentrations of $\mathrm{NO}_{3}-\mathrm{N}$ and $\mathrm{NH}_{4}-\mathrm{N}$ were present in the upstream (2.09 and $0.038 \mathrm{mg} \mathrm{I}^{-1}$ ) and downstream groundwaters $\left(2.6\right.$ and $\left.0.095 \mathrm{mgl}^{-1}\right)$. Low concentrations of these nutrients at the upstream surface water station reflect the low intensity landuse of the upstream drainage catchment (e.g. Mangatarere Valley), while elevated groundwater concentrations indicate the flushing of agricultural nutrients through the soil profile into the groundwater wells from rainfall-recharge (Saffigna and Keeney, 1977; Whittemore et al., 1989; Rozemeijer and Broers, 2007). $\mathrm{NO}_{3}-\mathrm{N}$ and $\mathrm{NH}_{4}-\mathrm{N}$ concentrations were slightly elevated in the downstream surface water site $\left(0.48\right.$ and $\left.0.1 \mathrm{mgl}^{-1}\right)$ in comparison to those recorded upstream.

20 Upstream groundwater EC remained relatively consistent for the duration of the study period (ca. $198 \mu \mathrm{S} \mathrm{cm}^{-1}$ ). Three dilution events were experienced on JD356, 005 and 021-030 in which conductivity decreased ca. $5 \mu \mathrm{sm}^{-1}$ for the first two events and $50 \mu \mathrm{sm}^{-1}$ for the last event (Fig. 3). The first two events can be explained by purging of the well that resulted in dilute waters from within the aquifer being drawn into the well casing (Wilson and Rouse, 1983; Reilly and Gibs, 1993) and/or possible instrumentation error due to the accuracy of the CS547A probe (accuracy $\pm 10 \%$ ). The larger event on JD021-030 occurred during an extended precipitation event (ca. $102 \mathrm{~mm}$ ) and the hydrochemical grab sampling programme (see Sect. 3.2). This suggests the input of younger dilute waters from precipitation, river waters and/or from within the

10238
HESSD

8, 10225-10273, 2011

\section{Investigation of groundwater-surface water interaction}

M. R. Guggenmos et al.

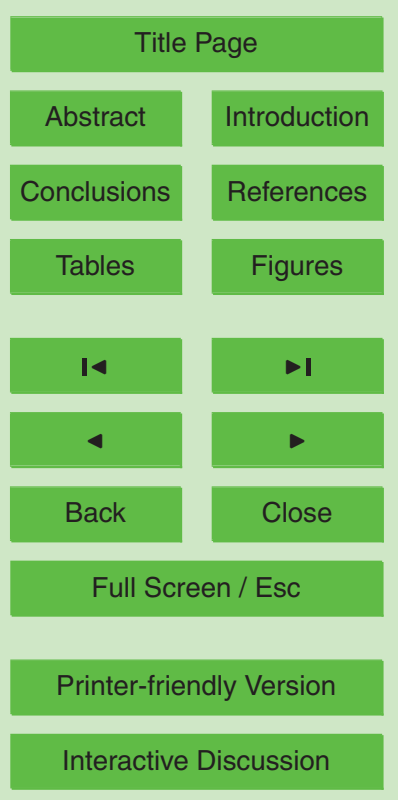


aquifer. Solute concentrations varied across the four gauging stations and $\mathrm{Na}$ was the only detectable ion of those measured in precipitation $\left(0.065 \mathrm{mgl}^{-1}\right)$ as presented in Table 2. Similarities did exist between the groundwater and surface water sites with $\mathrm{Na}$ and $\mathrm{Ca}$ the dominant cations and $\mathrm{HCO}_{3}^{-}$and $\mathrm{Cl}^{-}$the dominant anions in solution

5 (Table 2). As the concentration of solutes in precipitation are extremely low, and only $\mathrm{Na}$ was detected, it can be assumed the majority of these solutes are acquired through mineral dissolution of the sedimentary and metamorphic lithology of the Mangatarere catchment (Schmalz, 1972).

\subsection{Temporal variability in catchment hydrochemistry}

10 A broad hydrochemical survey of both the surface water and groundwater gauging stations was undertaken during JD021-028 to investigate daily and diurnal changes in water chemistry in order to improve our understanding of potential aquifer-stream transfer. As shown in Fig. 3, surface water and groundwater EC show significant temporal variability over this period in response to precipitation events. This variability is 5 also reflected in surface water and groundwater solute concentrations obtained during the hydrochemical sampling programme. Generally, upstream and downstream surface water solute concentrations followed a similar pattern throughout the week in which concentrations of $\mathrm{Ca}, \mathrm{Cl}^{-}, \mathrm{Na}, \mathrm{Mg}$ and $\mathrm{SO}_{4}{ }^{2-}$ decreased slightly on JD023 in response to increased precipitation and river stage (Fig. 4). Following this dilution, 20 solute concentrations showed a general increase as the receding limb of the storm hydrograph eased and base flow conditions resumed. The analytes total dissolved $\mathrm{P}$ and $\mathrm{NH}_{4}-\mathrm{N}$ were exceptions to this decrease. Both analytes showed a steady increase in their concentrations at the downstream surface water station, while concentrations remained relatively consistent at the upstream surface water gauging station. 25 Concentrations of the ions $\mathrm{Ca}, \mathrm{HCO}_{3}^{-}, \mathrm{SO}_{4}{ }^{2-}$ and $\mathrm{Na}$ showed an overall decrease at the upstream groundwater site in response to precipitation, while $\mathrm{Cl}^{-}$concentrations remained consistent at $12 \mathrm{mgl}^{-1}$. Upstream groundwater $\mathrm{NO}_{3}-\mathrm{N}$ concentrations
HESSD

8, 10225-10273, 2011

\section{Investigation of groundwater-surface water interaction}

M. R. Guggenmos et al.

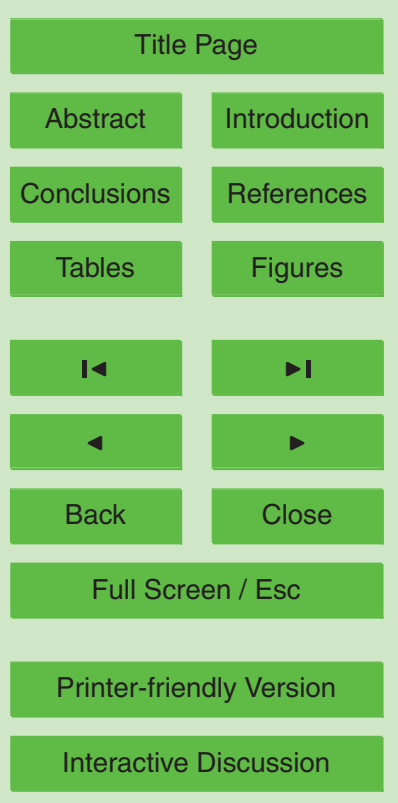


increased to $2.6 \mathrm{mgl}^{-1}$ on JD025 before decreasing for the remainder of the sampling period to $1.5 \mathrm{mgl}^{-1}$ on JD028. These chemical dynamics suggest the input of dilute waters to the groundwater system, subsequently reducing $\mathrm{Ca}, \mathrm{HCO}_{3}^{-}, \mathrm{SO}_{4}{ }^{2+}$ and $\mathrm{Na}$ concentrations. As $\mathrm{Cl}^{-}$concentrations remained consistent, and an initial pulse of $5 \mathrm{NO}_{3}-\mathrm{N}$ was experienced; this suggests these two solutes are acquired by the passage of dilute precipitation waters through the vadose zone (Taylor et al., 1999; Rosen et al., 1999). This indicates rainfall recharge to the groundwater system resulting in the significant groundwater stage increase and a reduction in groundwater conductivity (Fig. 3). The analytes $\mathrm{K}, \mathrm{Mg}, \mathrm{NO}_{3}-\mathrm{N}$ and $\mathrm{Mn}$ fluctuated at the upstream groundwater site during the hydrochemical sampling period (Fig. 4). In particular, K showed considerable variation during the $24 \mathrm{~h}$ intensive sampling program, fluctuating ca. $0.4 \mathrm{mg} \mathrm{l}^{-1}$ (Table 2). This variability in $\mathrm{K}$ concentrations may be an indication of cation exchange (Rosenthal, 1987; McLaren and Cameron, 2006) and highlights the significant temporal variability of these analytes within a sub-daily time period. This variability may be further ex5 plained by purging of the groundwater well that resulted in dilute waters being drawn into the well casing. This water may have mixed with existing well waters, creating temporal variations in all measured parameters. This hypothesis is further supported by the noticeable fluctuations (ca. $5-10 \mu \mathrm{S} \mathrm{cm}^{-1}$ ) in upstream groundwater EC during the hydrochemical sampling programme. These fluctuations occurred in response to well purging and the subsequent reductions in groundwater stage (ca. 5-35 cm). Both groundwater stage and EC readjusted themselves in the hour immediately following water extraction. This suggests that although groundwater purging can influence the hydrological and hydrochemical properties of the upstream groundwater well over short time scales, this influence is quickly counterbalanced by natural well processes. There- fore, it is unlikely groundwater purging influenced the long term chemical composition of the groundwater wells. However, it is possible such purging influenced the chemical composition of individual grab samples that were extracted immediately following well purging. This potential influence will be discussed in further detail in Sect. 5.
HESSD

8, 10225-10273, 2011

\section{Investigation of groundwater-surface water interaction}

M. R. Guggenmos et al.

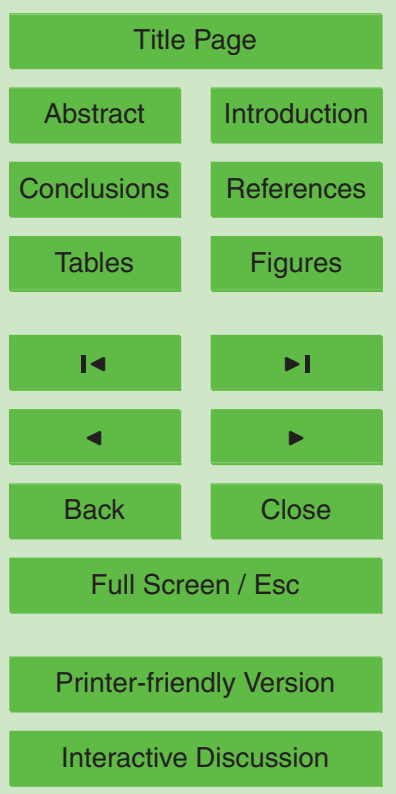




\subsection{Upstream Mangatarere groundwater and surface water interaction}

Results indicate clear differences in the hydrological and chemical responses between the upstream and downstream gauging locations and the surface water and groundwater gauging stations. This spatial variability is also inherent in the systems of interaction 5 between surface water and groundwater bodies in the Mangatarere catchment.

It appears the upstream groundwater station receives recharge primarily from rainfall, as indicated by elevated $\mathrm{NO}_{3}-\mathrm{N}, \mathrm{Cl}^{-}$and $\mathrm{Na}$ concentrations, ions known to accumulate during the passage of precipitation through the soil-water zone (Taylor et al., 1989). However, significant recharge is also likely provided by the neighboring Man10 gatarere stream, as indicated by concurrent increases in upstream surface and groundwater stage on JD334-339, 348-350 and 021-025 (Fig. 3). This provision of surface water recharge is based on the theory that as surface water stage increases water may move through the stream bed to underlying groundwater systems resulting in a subsequent increase in groundwater stage. This is a relatively common phenomenon and is 15 extensively documented in the literature (e.g. Dahan et al., 2008; Schmalz et al., 2007; Winter et al., 2008), however it is hard to support this hypothesis based on water stage data alone.

Water and air temperature data provided further insight into this potential upstream interaction and are presented in Fig. 5. Upstream and downstream surface water temperatures followed a similar diurnal pattern to that of air temperature, indicative of solar heating. In contrast, upstream groundwater temperatures showed a consistent increase in water temperature $\left(12.4^{\circ} \mathrm{C}\right.$ to $\left.13.5^{\circ} \mathrm{C}\right)$ during the study period JD323-051. This increase is to be expected as groundwater temperatures generally vary according to long term mean air temperature (Brunke and Gonser, 1997) which increased in the Mangatarere catchment as the summer progressed. Although downstream groundwater data were not available it is likely the downstream site followed a similar pattern to that experienced at the upstream groundwater station. On JD026-028 upstream groundwater temperature displayed a weak diurnal pattern increasing ca. $0.1-0.2^{\circ} \mathrm{C}$ during the day (Fig. 5). This diurnal pattern was not experienced at any other time
HESSD

8, 10225-10273, 2011

\section{Investigation of groundwater-surface water interaction}

M. R. Guggenmos et al.

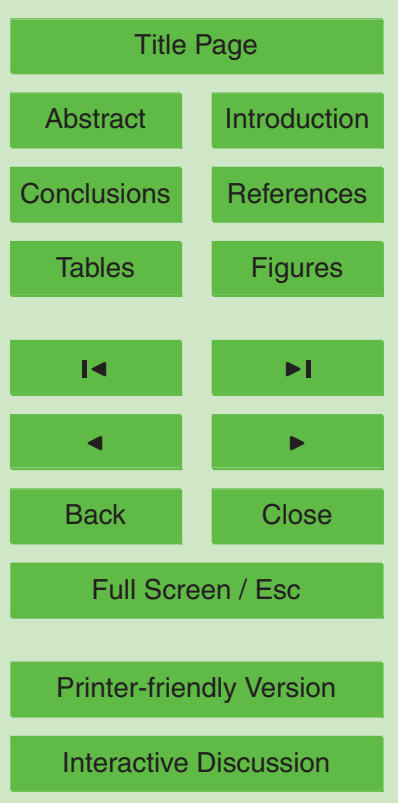


during the study and occurred concurrently with diurnal patterns in air and surface water temperatures. This suggests the transfer of diurnal temperature changes from the Mangatarere stream to the upstream groundwater aquifer and indicates a potential hydraulic link between the two systems during this three day period. The overall warming 5 or cooling of groundwater temperatures in response to river recharge has been documented in the literature (e.g. Silliman and Booth, 1993; Constanz, 1998), however river recharge is not known to create diurnal patterns in groundwater temperature. Another explanation for this diurnal phenomenon is reported by Duque et al. (2010). This research suggests groundwaters may display a similar pattern to that of air temperature 10 as the water table approaches the land surface and is influenced by radiant energy from the sun. It is unlikely this air temperature response is applicable for this current situation, as upstream groundwater temperatures did not show a diurnal response during other periods of the study when the distance between the water table and ground surface was similar (e.g. JD337-339) (Fig. 3). Further, the conductive transport of heat 15 from the atmosphere through the soil zone would have been heavily reduced by the presence of pastoral grass on the ground surface and the various layers of sand and silt which display low thermal conductance values (Baver, 1940; Campbell, 1985).

This diurnal groundwater temperature pattern was not observed at any other period of the study. This suggests, despite these three concurrent surface and groundwater stage increases, that significant interaction between the upstream gauging stations may only have occurred during the period JD026-028.

Research by Dahan et al. (2008) emphasizes the duration of peak flows as an important factor that determines river recharge flux to groundwater bodies. Therefore, in order to gain further insight into the potential groundwater and surface water interaction during these three events we undertook an analysis of storm hydrographs (Fig. 6). During the two events on JD334-340 (Fig. 6a) and JD345-350 (Fig. 6b) surface water stage showed a rapid response to rainfall, as indicated by a sharp rising limb and relatively short falling limbs as water was quickly removed from the catchment. The increase in groundwater stage during these two events was slightly delayed, suggesting
HESSD

8, 10225-10273, 2011

\section{Investigation of groundwater-surface water interaction}

M. R. Guggenmos et al.

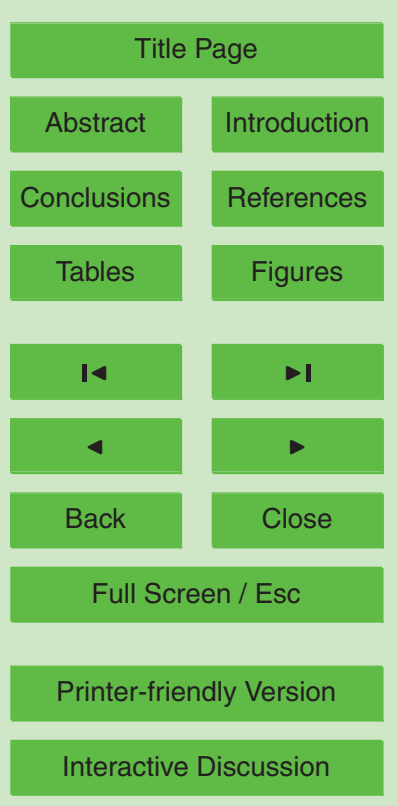


slow infiltration of precipitation through the soil-water zone or recharge from far away sources such as the Mangatarere stream. In contrast, groundwater stage showed an almost immediate response to either precipitation or surface water stage during the event on JD022-027 (Fig. 6c), suggesting initial high soil moisture conditions. Further, 5 surface waters displayed a gradual and extended falling limb that incorporated the two day period in which the diurnal water temperature fluctuation was detectable at the upstream groundwater station. This suggests, as noted by Dahan et al. (2008), that an extended high duration flow event may be needed to initiate river recharge to the upstream groundwater station and that interaction may occur in the days following peak 10 flows when surface water stage is reduced (e.g. JD026-028).

The importance of this three day period for river recharge is further highlighted through an analysis of water chemistry. During JD026-028, concentrations of rainfall accumulated $\mathrm{NO}_{3}-\mathrm{N}$ decreased at the upstream groundwater station and the sites chemical signature changed to a Na-Ca-Mg- $\mathrm{HCO}_{3}^{-}-\mathrm{Cl}^{-}$water, indicating the increased 15 importance of $\mathrm{Cl}^{-}$during this period (Table 3). This $\mathrm{Na}-\mathrm{Ca}-\mathrm{Mg}-\mathrm{HCO}_{3}^{-}-\mathrm{Cl}^{-}$water type with reduced concentrations of $\mathrm{NO}_{3}-\mathrm{N}$ is very similar to that presented at the upstream surface water station ( $\mathrm{Na}-\mathrm{Ca}-\mathrm{HCO}_{3}^{-}-\mathrm{Cl}^{-}$) suggesting the transfer of surface waters to the aquifer during this period. Upstream groundwater $\mathrm{Ca} / \mathrm{Na}$ ratios also decreased during these last three days from 6-6.83 to 5.41-5.91, which together with the $\mathrm{Cl}^{-} / \mathrm{HCO}_{3}^{-}$ 20 ratios, suggest the increased importance of $\mathrm{Na}$ and $\mathrm{Cl}^{-}$in the sample waters (Table 3). Due to the extremely low concentrations of all ions in precipitation (Table 2) it is likely this $\mathrm{Na}$ was sourced from river waters and the dissolution of sedimentary rocks in the Mangatarere's catchment. These ratios would likely be higher at the upstream groundwater station if waters were sourced entirely from rainfall-recharge because precipita25 tion would provide more $\mathrm{Ca}$ and $\mathrm{HCO}_{3}^{-}$to solution from the dissolution of Quaternary alluvial gravels through which these waters pass. An alternative explanation surrounds the input of additional $\mathrm{Ca}$ ions from carbonate dissolution, that subsequently bump $\mathrm{Na}$ into solution therefore increasing their concentration and proportionality (McLaren and Cameron, 2006).
HESSD

8, 10225-10273, 2011

\section{Investigation of groundwater-surface water interaction}

M. R. Guggenmos et al.

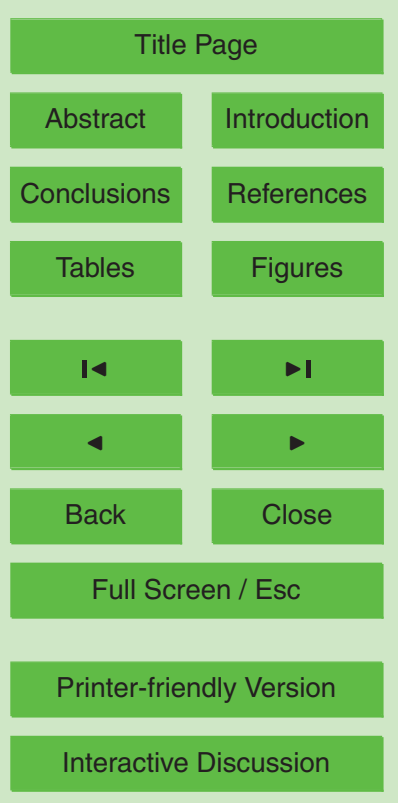

10243 


\subsection{Downstream Mangatarere groundwater and surface water interaction}

It is somewhat harder to make inferences regarding groundwater and surface water interaction at the downstream monitoring area due to the loss of all high resolution data from the downstream groundwater gauging station. However, despite this obvious

5 limitation some inferences can be made from surface water data, the hydrochemical sampling programme and upstream groundwater data. The assumption is made that the upstream and downstream groundwater gauging stations share similar hydrological and chemical characteristics and respond in a comparable manner because they are part of the wider Carterton sub-regional flow system.

10 It appears that a significant proportion of downstream surface water base flow is provided by solute rich groundwaters, as indicated by higher average downstream surface water EC (ca. $100-110 \mu \mathrm{S} \mathrm{cm}^{-1}$ ) in comparison to that experienced upstream (ca. $80 \mu \mathrm{Scm}^{-1}$ ) (Fig. 3). This is supported by elevated concentrations of TDS (49.9 $\mathrm{mgl}^{-1}$ upstream and $65.7 \mathrm{mgl}^{-1}$ downstream) and $\mathrm{NO}_{3}-\mathrm{N}, \mathrm{NH}_{4}-\mathrm{N}, \mathrm{Na}$ and $\mathrm{Cl}^{-}$ 15 at the downstream surface water station (Table 2). These elements are known to accumulate in rainfall-recharged groundwaters and are likely to have been transferred to the downstream surface water site through the provision of groundwater base flow. Similar results have been extensively documented in the literature by Burden (1982), Taylor et al. (1989) and Rozemeijer and Broers (2007). Further, high resolution hydrochemical monitoring undertaken during JD021-028 shows a selective increase in $\mathrm{P}$ and $\mathrm{NH}_{4}-\mathrm{N}$ concentrations at the downstream surface water gauging station. These analytes remained relatively consistent upstream during the same period, and therefore are likely to have been transferred to downstream surface waters from neighboring groundwaters or from tributary streams.

25 This hypothesis of downstream surface waters gaining base flow from groundwater is further supported by the subdued surface water temperature experienced at the downstream site. Upstream and downstream surface water temperatures followed a similar diurnal pattern to that of air temperature, however diurnal variations were dampened
HESSD

8, 10225-10273, 2011

\section{Investigation of groundwater-surface water interaction}

M. R. Guggenmos et al.

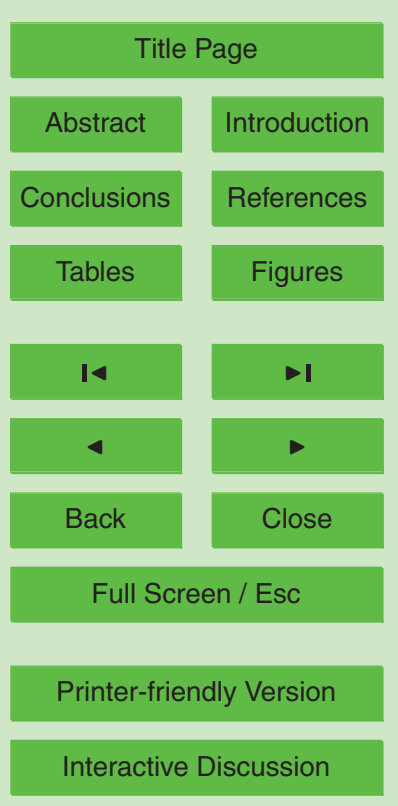


at the downstream surface water site (downstream range $12-22^{\circ} \mathrm{C}$, upstream range $10-25^{\circ} \mathrm{C}$ ) (Fig. 5). This reduced downstream thermal signature suggests the provision of groundwater base flow at the downstream surface water site in which a greater proportion of flow is provided by consistently cooler groundwaters. Meteorological energy 5 inputs are subdued as advective inputs of groundwater are enhanced (O'Driscoll and DeWalle, 2006). This dampening of diurnal water temperatures in response to groundwater inputs has also been reported by Constanz (1998) in a small alpine stream in the Colorado Rockies. Although downstream groundwater temperature data are not available, it can be assumed based on upstream groundwater data and examples from 10 the literature (e.g. Constanz, 1998; Silliman and Booth, 1993; O'Driscoll and DeWalle, 2006), that these downstream groundwaters would also be substantially colder and display a more consistent temperature.

If groundwaters were not providing a significant proportion of base flow to the downstream surface water site or if the downstream Mangatarere provided recharge to un15 derlying groundwaters it would be assumed that downstream solute concentrations and TDS would more closely resemble those of the upstream surface water site. Other explanations for this increased downstream surface water TDS include similar groundwater base flow proportions but increased mineral dissolution and/or the input of point or non-point contaminants. We suggest neither of these explanations are particularly plausible as significant mineral dissolution is unlikely to have occurred in the short distance between the two gauging locations (ca. $10 \mathrm{~km}$ ) and the geology between the two gauging catchments is relatively uniform (Fig. 2a). Further, the increase in solutes is not ion specific as would be expected from point source inputs (e.g. only elevated $P$ and $\mathrm{NO}_{3}^{-} \mathrm{N}$ as presented by Saffigna and Keeney, 1977). \\ 4.6 Quantification of temporal variability in groundwater and surface water interaction}

To further explore the interaction between the upstream and downstream surface water and groundwater bodies we employed two simple mass balance calculations. These 10245
HESSD

8, 10225-10273, 2011

\section{Investigation of groundwater-surface water interaction}

M. R. Guggenmos et al.

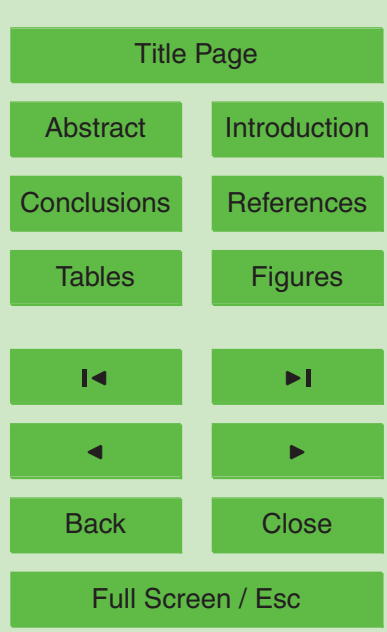

Printer-friendly Version

Interactive Discussion 
calculations allowed for the temporal quantification of water transfer between the various gauging stations. Similar mass balance methods have been used in the literature to separate storm flows into pre-event, event, soil and groundwater components (e.g. Hooper et al., 1990; Mulholland, 1993; Laudon and Slaymaker, 1997). It is ac5 knowledged that a number of limitations surround the calculations employed in this research, therefore we do not wish to overemphasize such findings.

The first of such calculations aimed to quantify the average daily river recharge provided to the upstream groundwater station by determining the loss of surface water between the upstream surface water gauging station and the historic Mangatarere at 10 Gorge monitoring station located ca. 2 km upstream (Refer to Fig. 2 for locations).

Average daily discharge measurements were determined at both stations using average daily water stage $(x)$ and a stage-discharge rating curve $\left(y=6.5967 x^{3.3547}\right.$ and $y=9.2531 \times{ }^{3.0892}$ for the upstream and downstream stations respectively). Full workings and assumptions surrounding these rating curves are presented in Appendix A.

15 The resulting output is presented in Fig. 7 and shows the predicted average daily discharge $\left(\mathrm{m}^{3} \mathrm{~s}^{-1}\right)$ for the two gauging stations during the period JD324-038. Stage data were not available from the Mangatarere at Gorge station from JD039-051 therefore we excluded this period because discharge could not be determined. Despite several anomalies within the timeframe, in which discharge was higher at the upstream surface water station than the Mangatarere at Gorge, it appears the majority of recharge to the upstream groundwater system was provided during high flow events (Fig. 7). This is indicated by the loss of flow between the Mangatarere at Gorge and the upstream surface water gauging station on JD332-336, 348, 354, 004, 012, 017, 023 and 031-34. It is likely that during these events water was able to move through the stream bed and banks and into underlying groundwater systems as discharge increased. Analyses from Fig. 3 showed that upstream groundwater stage only responded to possible recharge on JD335, 348 and 021-025. This supports our initial assumptions that although water may have been lost to the groundwater system during other periods a certain magnitude of recharge or high antecedent soil moisture conditions is required
HESSD

8, 10225-10273, 2011

\section{Investigation of groundwater-surface water interaction}

M. R. Guggenmos et al.

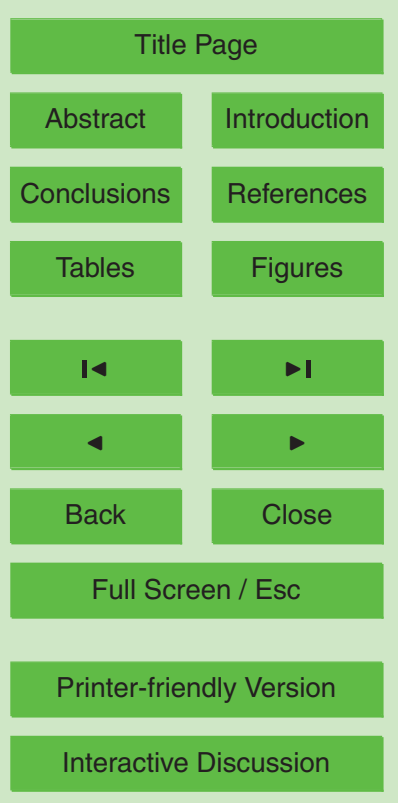

10246 
to initiate a groundwater stage response. Figure 7 suggests ca. $2-4 \mathrm{~m}^{3} \mathrm{~s}^{-1}$ of upstream Mangatarere flow was lost to the underlying groundwater system during the three groundwater stage response events on JD335, 348 and 021-025.

A second mass balance calculation was employed to quantify the proportion of daily 5 base flow provided to the downstream surface water gauging station by groundwater sources. This model incorporated the parameter EC and assumed changes in average daily downstream surface water conductivity and discharge were due to changes in discharge and $\mathrm{EC}$ at the upstream surface water gauging station and the input of base flow of a known EC from the upstream groundwater gauging station. Discharge rating curves and the assumptions surrounding this calculation are presented in Appendix B.

From Fig. 8 it appears ca. 30-60\% of downstream surface water base flow was provided by the neighboring groundwater aquifer during the period JD345-051. This proportion varied significantly over the 72 day modeled period and on average changed on a day to day basis. Generally the proportion of groundwater provided base flow decreased during high flow events, despite higher input quantities, when the majority of discharge was provided to the downstream Mangatarere from direct rainfall runoff and the upstream surface water gauging station. For the majority of the modeled study period downstream surface water discharge was ca. $60 \%$ higher than that experienced upstream. This difference in surface water discharge was already inferred from stage data (Fig. 3) and is likely due to the downstream stations larger catchment area $\left(130 \mathrm{~km}^{2}\right)$ and input from groundwaters.

During the period JD004-012 downstream discharge dropped ca. $0.3 \mathrm{~m}^{3} \mathrm{~s}^{-1}$ below upstream projections and the provision of groundwater base flow to the downstream station ceased. This discharge discrepancy suggests that downstream surface waduring this period switched the direction of interaction. Following several days of precipitation (JD010-012) and possible river recharge to the groundwater system it appeared this gradient switched back (JD012) and groundwaters once again provided base flow to the downstream surface water station. Following significant precipitation

HESSD

8, 10225-10273, 2011

\section{Investigation of groundwater-surface water interaction}

M. R. Guggenmos et al.

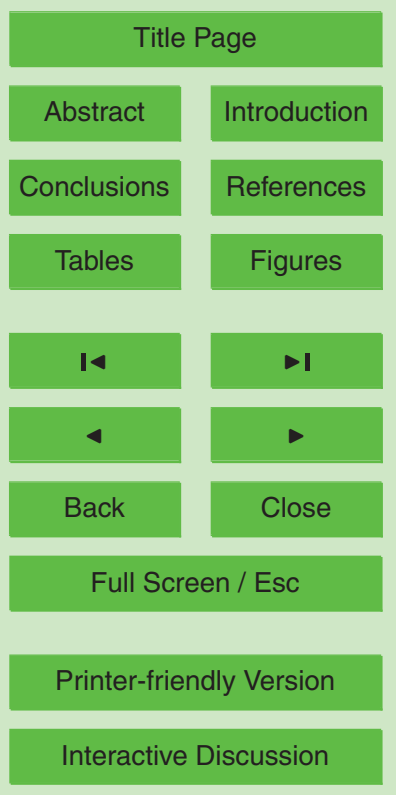

Interactive Discussion 
on JD020-023 up to $62 \%$ of downstream base flow was provided by the groundwater system (Fig. 8). These input waters (ca. 1.5-3 $\mathrm{m}^{3} \mathrm{~s}^{-1}$ ) extended the downstream gauging station's receding flood limb while upstream flood waters were quickly removed from the upstream catchment. The increased provision of base flow during this pe5 riod is likely due to increased downstream groundwater stage as suggested by the ca. $50 \mathrm{~cm}$ increase in upstream groundwater stage (Fig. 3). It is hard to confirm this hypothesis without downstream groundwater data, however, the increased importance of groundwater base flow during this period is further supported by a gradual increase in $\mathrm{NO}_{3}-\mathrm{N}, \mathrm{NH}_{4}-\mathrm{N}$ and $\mathrm{P}$ concentrations at the downstream surface water station from 10 JD023-028 (Fig. 4).

Although a number of major limitations and assumptions surround these mass balance calculations, they provide further evidence to support hypotheses already stated in Sects. 4.4 and 4.5. It is likely significant uncertainty surrounds the calculation of discharge, in particular where foreign rating curves are applied to the upstream surface

water gauging station. Therefore, we have employed a precautionary approach when interpreting the magnitude of interaction and findings from this section are only used to support initial assumptions already outlined. We acknowledge the significant insight mass balance calculations may provide in the investigation of stream-aquifer transfer, however future research is needed in order to determine robust stage-discharge rating

\section{Conclusions and implications}

The data presented in this study demonstrate the spatial and temporal variability of surface water and groundwater interaction in the Mangatarere stream catchment. Despite being only $10 \mathrm{~km}$ apart the upstream and downstream monitoring areas displayed contrasting mechanisms of stream-aquifer transfer. The upstream groundwater station appeared to receive recharge primarily from precipitation, but also from interaction with the Mangatarere stream. Concentrations of upstream groundwater $\mathrm{NO}_{3}-\mathrm{N}, \mathrm{Cl}^{-}$ and $\mathrm{Na}$ were significantly higher than those experienced in upstream surface waters,

HESSD

8, 10225-10273, 2011

\section{Investigation of groundwater-surface water interaction}

M. R. Guggenmos et al.

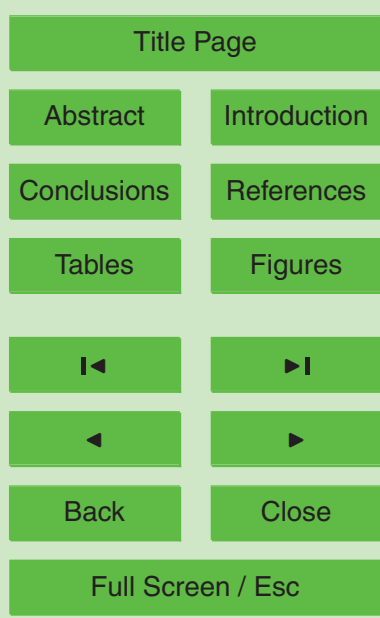

Printer-friendly Version

Interactive Discussion 
suggesting their accumulation during the passage of precipitation through the soilwater zone. However, upstream groundwater stage data and mass balance calculations suggest river recharge was provided to the upstream groundwater station on JD335, 348 and 021-028. This hypothesis is increasingly clear for the latter event 5 as supported by a decrease in $\mathrm{NO}_{3}-\mathrm{N}$ concentrations at the upstream groundwater station and the dominant upstream groundwater type becoming $\mathrm{Na}-\mathrm{Ca}-\mathrm{Mg}-\mathrm{HCO}_{3}^{-}-\mathrm{Cl}^{-}$ as low $\mathrm{NO}_{3}-\mathrm{N}$ surface waters recharged the aquifer from JD026-028. Furthermore, a diurnal water temperature pattern was transferred from the Mangatarere stream to the upstream groundwater station during this period. These findings show that the in10 teraction between groundwater and surface water at the upstream Mangatarere to be temporally complex, and influenced by both meteorological and fluvial processes.

In contrast, the downstream surface water gauging station appears to receive a more significant proportion of base flow from the neighboring groundwater aquifer. This was indicated by a subdued diurnal water temperature and overall colder water temperatures at the downstream gauging station. Downstream surface water EC and solute concentrations were significantly higher than those experienced at the upstream surface water station, again indicating a supply of solute rich groundwaters to stream base flow. This hypothesis was further supported by elevated $\mathrm{NO}_{3}-\mathrm{N}, \mathrm{Na}$ and $\mathrm{Cl}^{-}$ concentrations in downstream surface waters, analytes known to accumulate in rainfallrecharged groundwaters. In addition, the data presented here unearth the complexities of surface water and groundwater interaction at the downstream monitoring area with mass balance calculations and stage data suggesting $30-60 \%$ of downstream surface water base flow was provided by neighboring groundwaters. This proportion of groundwater provided base flow can vary significantly over short timescales (e.g. daily) and during the period JD004-016 it appears a change in hydraulic gradient occurred with downstream surface waters providing recharge to the groundwater system in response to an extended dry period.

The hydrochemical sampling programme undertaken during JD021-028 resulted in subsequent groundwater stage and EC responses at the upstream gauging station.
HESSD

8, 10225-10273, 2011

\section{Investigation of groundwater-surface water interaction}

M. R. Guggenmos et al.

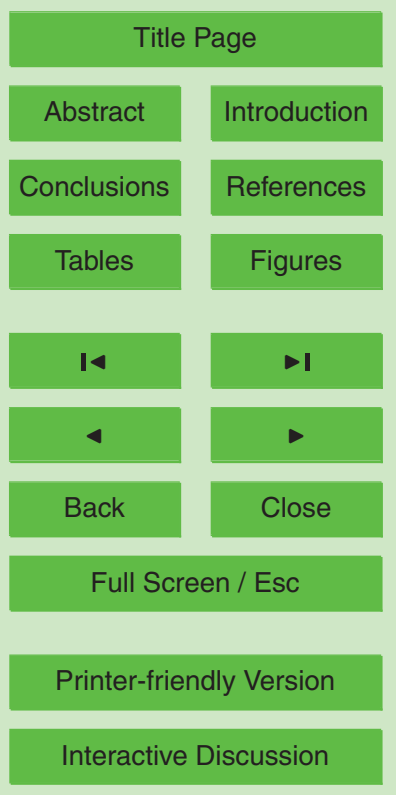

10249 
Although this method of analysis provided considerable insight into surface water and groundwater interaction in the Mangatarere catchment, extended purging of the groundwater well may have affected the hydrochemical composition of well waters. Continuous upstream groundwater EC measurements showed a clear decrease as 5 new dilute aquifer waters were drawn into the well casing, a phenomenon that is likely to have affected solute concentrations. This sampling artifact highlights issues surrounding the collection and use of high frequency hydrochemical grab samples from shallow groundwater wells. Although the scientific community is calling for more high resolution chemical data (e.g. Kirchner, 2006), there is a danger that this request may 10 introduce significant error to new datasets and their subsequent interpretations. In order to establish the full extent to which high frequency hydrochemical sampling affects solute concentrations further research is needed.

This paper utilized a number of standard hydrological and chemical techniques to investigate the high resolution interaction of surface water and groundwater in the Man15 gatarere catchment. Although each of these techniques brought considerable insight to our understanding of surface and groundwater transfer, they each have their individual limitations and levels of uncertainty and in combination were significantly more powerful than the sum total of what could be inferred from individual methods. Results therefore support the guidance provided by Kalbus et al. (2006), that a multi-method approach, in which various investigative techniques are combined, is likely to provide the most certainty as well as provide some leeway for instrumentation redundancies.

The loss of continuous measurements from the downstream groundwater gauging station introduced an unforeseen but major limitation to this investigation and highlights the need to factor instrumentation redundancies into monitoring networks. Although inferences were made about the downstream system using available data, the robustness of these inferences would have been improved and further process understanding gained if this instrumentation failure had not occurred. It is recommended that future monitoring programmes include a greater number of gauging stations to allow for the loss of some stations and therefore datasets.
HESSD

8, 10225-10273, 2011

\section{Investigation of groundwater-surface water interaction}

M. R. Guggenmos et al.

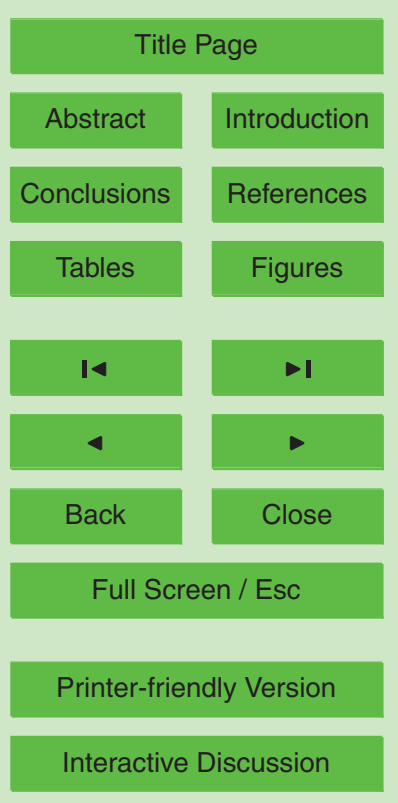

10250 
Findings presented in this paper support results from a regional study presented in Guggenmos et al. (2011) that used regional monitoring data to identify a variety of sites of potential interaction in the Wairarapa Valley including the downstream section of the Mangatarere stream. Guggenmos et al. (2011) suggested the downstream 5 Mangatarere received a significant proportion of base flow from groundwater sources. This was inferred through the classification of the Mangatarere stream and neighboring downstream groundwaters into a single hydrochemical facies based on similarities in $\mathrm{Na}, \mathrm{Cl}^{-}$and $\mathrm{NO}_{3}-\mathrm{N}$ concentrations. The findings of this study support this assumption, as well as adding process understanding that could not have been gleaned from the 10 regional study alone. Furthermore, this study has shown that this interaction is spatially complex and displays a wide degree of temporal variability, on sub-daily as well as longer (monthly) timescales. In order to capture temporal variability of this scale in surface water and groundwater interaction, high frequency hydrochemical sampling and monitoring is required. This highlights the potential of using multivariate statistical methods and historic hydrochemical medians to provide a rapid and cost-effective preliminary screening method to identify areas of potential groundwater and surface water interaction. The use of such preliminary investigations is likely to reduce the chance of investigating areas of little interest and these locations can be further validated and investigated using a range of field techniques such as those employed in this paper.

There is still much to be learned about the complex nature surrounding groundwatersurface water interactions and the principal processes that influence this phenomenon across various temporal scales and climatic and geomorphic environments. Although we have demonstrated the need for high frequency datasets, long term datasets are still required to elucidate the role seasonal cycles and environmental change may have on such processes. The establishment of long term high resolution hydrological and chemical monitoring programmes will allow the scientific community to determine not only seasonal changes in this interaction but also sub-daily changes that were previously ignored.
HESSD

8, 10225-10273, 2011

\section{Investigation of groundwater-surface water interaction}

M. R. Guggenmos et al.

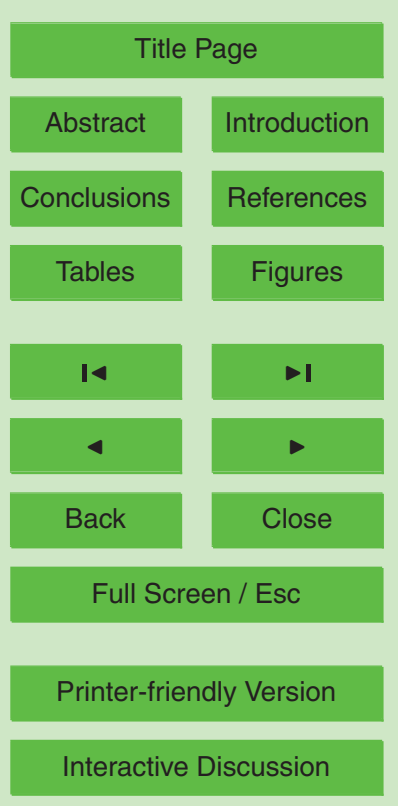




\section{Appendix A}

HESSD

\section{Stage-discharge rating curves}

See Figs. A1-A2 and Tables A1-A2.

\section{Appendix B}

\section{Mass balance calculations}

The first of such calculations aimed to quantify the average daily river recharge $\left(Q_{r}\right)$ provided to the upstream groundwater station by determining the loss of surface water between the upstream surface water gauging station $\left(Q_{\mathrm{u}}\right)$ and the historic upstream Mangatarere at Gorge monitoring station maintained by the GWRC $\left(Q_{m}\right)$ (Refer to Fig. 2 for locations).

Neglecting evaporation and water abstraction for consumptive use, which were deemed minimal, it was assumed that discharge $\left(\mathrm{m}^{3} \mathrm{~s}^{-1}\right)$ lost between these two stations was due to recharge of the underlying aquifer. The following equation was used to determine river recharge:

$Q_{\mathrm{r}}=Q_{\mathrm{m}}-Q_{\mathrm{u}}$

Where: $Q_{\mathrm{r}}=$ recharge to upstream groundwater station $\left(\mathrm{m}^{3} \mathrm{~s}^{-1}\right) ; Q_{\mathrm{m}}=$ Mangatarere at Gorge discharge $\left(\mathrm{m}^{3} \mathrm{~s}^{-1}\right) ; Q_{\mathrm{u}}=$ upstream gauging station discharge $\left(\mathrm{m}^{3} \mathrm{~s}^{-1}\right)$

This rating curve was determined for the Mangatarere at Gorge station (using interpolated GWRC data) and was deemed applicable to the upstream surface water gauging station due to cross sectional and environmental similarities (e.g. vegetation, stream bed sediment roughness and size) between the sites. Further, no major tributary inputs are present in the ca. $2 \mathrm{~km}$ reach between the two gauging locations. Error

Investigation of groundwater-surface water interaction

M. R. Guggenmos et al.

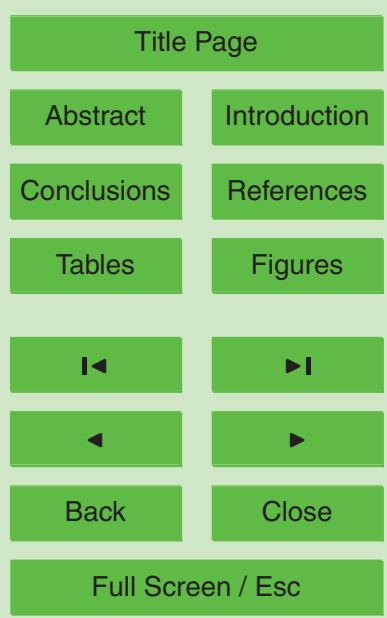

Printer-friendly Version

Interactive Discussion 
estimates of \pm 15 and $\pm 20 \%$ were placed on predicted discharge measurements from the Mangatarere at Gorge and upstream surface water station respectively. The higher error at the upstream surface water site reflects the application of a foreign rating curve to this site.

5 A second mass balance calculation was employed to quantify the proportion of daily base flow $\left(\mathrm{GW}_{\mathrm{b}}\right)$ provided to the downstream surface water gauging station by groundwater sources. This model incorporated the parameter EC and assumed changes in average daily downstream surface water conductivity $\left(E C_{d}\right)$ and discharge $\left(Q_{d}\right)$ were due to changes in discharge and EC at the upstream surface water gauging station ${ }_{10}\left(Q_{\mathrm{su}}\right.$ and $\left.\mathrm{EC}_{\mathrm{su}}\right)$ and the input of base flow of a known $\mathrm{EC}$ from the upstream groundwater gauging station $\left(\mathrm{GW}_{\mathrm{b}}\right.$ and $\left.\mathrm{EC}_{\mathrm{gw}}\right)$. The calculation is presented in Equation 2. Upstream groundwater EC data were used to represent the downstream groundwater station as measurements were not available from this site due to the loss of power. Furthermore, a lack of downstream surface water data during the period JD324-345 15 resulting in this period being excluded from the calculation.

$\mathrm{GW}_{\mathrm{b}}=\frac{\left(Q_{\mathrm{su}} \times \mathrm{EC}_{\mathrm{su}}\right)+\left(Q_{\mathrm{d}} \times \mathrm{EC}_{\mathrm{d}}\right)}{\mathrm{EC}_{\mathrm{gw}}}$

Where: $\mathrm{GW}_{\mathrm{b}}=$ groundwater input to downstream surface water station $\left(\mathrm{m}^{3} \mathrm{~s}^{-1}\right)$; $Q_{\text {su }}=$ Upstream surface water discharge $\left(\mathrm{m}^{3} \mathrm{~s}^{-1}\right) ; \mathrm{EC}_{\mathrm{su}}=$ Upstream surface water conductivity $\left(\mu \mathrm{Scm}^{-1} ; Q_{d}=\right.$ Downstream surface water discharge $\left(\mathrm{m}^{3} \mathrm{~s}^{-1}\right)$; $\mathrm{EC}_{\mathrm{d}}=$ Downstream surface water conductivity $\left(\mu \mathrm{S} \mathrm{cm}^{-1}\right) ; \mathrm{EC}_{\mathrm{gw}}=$ Downstream groundwater conductivity $\left(\mu \mathrm{S} \mathrm{cm}^{-1}\right)$.

Daily discharge measurements were determined at the upstream gauging station using the Mangatarere Gorge stage-discharge rating curve equation $\left(Q_{\mathrm{su}}=6.5967 \times{ }^{3.3547}\right)$ while a separate rating equation $\left(Q_{\mathrm{d}}=9.2531 \times{ }^{3.0892}\right)$ was de25 termined for the downstream gauging station using data provided by the GWRC. A number of assumptions were made for these calculations. These include:
HESSD

8, 10225-10273, 2011

\section{Investigation of groundwater-surface water interaction}

M. R. Guggenmos et al.

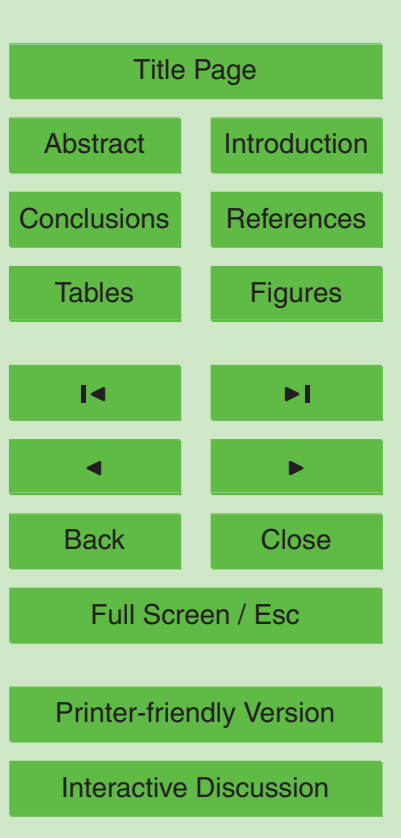

Interactive Discussion 
- The application of the Mangatarere at Gorge discharge rating curves to the upstream surface water gauging station is sufficient.

- Upstream groundwater data can be used as a surrogate for the downstream groundwater gauging station. This is based on the assumption that both gauging stations are within the Carterton sub-regional flow system and respond in a similar manner.

- It is assumed that no additional input of water from tributary streams occurs along the ca. $10 \mathrm{~km}$ reach between the upstream and downstream gauging locations. This assumption is flawed with several streams present (Fig. 2), however input from these streams is deemed minimal over the period of interest, so is unlikely to influence the overall findings from these calculations. This is formulated on the assumption, based on discharge data (Table 1), that inputs to the Mangatarere from these ephemeral streams during summer base flow conditions are extremely low $\left(<0.1 \mathrm{~m}^{3} \mathrm{~s}^{-1}\right)$. However, it must be noted that these tributaries may contribute waters during large flow events when they become active. The extent of this input cannot be quantified as these catchments are largely ungauged during such events. It must also be noted that the total downstream gauging catchment $\left(130 \mathrm{~km}^{2}\right)$ is $60 \%$ larger than the upstream surface water gauging station catchment $\left(52 \mathrm{~km}^{2}\right)$ due to the Enaki (ca. $32 \mathrm{~km}^{2}$ ) and Kaipatangata (ca. $23 \mathrm{~km}^{2}$ ) stream catchments that it encompasses.

- Outputs from evaporation, plant uptake and water abstraction for consumptive use are deemed minimal.

- Direct inputs from precipitation are deemed minimal.

Acknowledgements. This project was supported by a grant from the New Zealand Foundation of Research, Science and Technology (Contract C05X0906). The authors wish to thank the Greater Wellington Regional Council, which provided additional funding, logistical support and additional datasets for this project.
HESSD

8, 10225-10273, 2011

\section{Investigation of groundwater-surface water interaction}

M. R. Guggenmos et al.

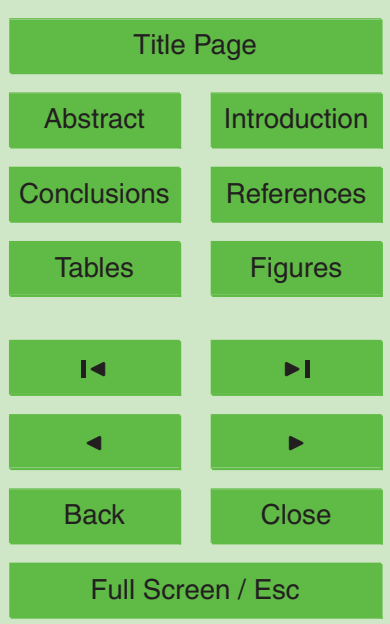

Printer-friendly Version

Interactive Discussion 


\section{References}

Berner, E. K. and Berner, R. A.: Global environment: Water, air and geochemical cycles, Prentice-Hall, Inc, New Jersey, 1996.

Bjerg, P. L. and Christensen, T. H.: Spatial and temporal small-scale variation in groundwater 5

Brunke, M. and Gonser, T.: The ecological significance of exchange processes between rivers and groundwater, Freshwater Biology, 37, 1-33, 1997.

Burden, R. J.: Hydrocemical variation in a water-table aquifer beneath grazed pastureland, J. Hydrol. (NZ), 21, 61-75, 1982.

Constanz, J.: Interaction between stream temperature, streamflow and groundwater exchanges in alpine streams, Water Resour. Res., 34, 1609-1615, 1998.

Cook, P. G., Favreau, G., Dighton, J. C., and Tickell, S.: Determining natural groundwater influx to a tropical river using radon, chlorofluorocarbons and ionic environmental tracers, J. Hydrol., 277, 74-88, 2003.

15 Dahan, O., Tatarsky, B., Kulls, C., Seely. M., and Benito, G.: Dynamics of flood water infiltration and groundwater recharge in Hyperarid Desert, Ground Water, 46, 450-461, 2008.

Guggenmos, M.: Groundwater and Surface water interaction, Wairarapa Valley, New Zealand Victoria University of Wellington, Wellington, 2010.

Guggenmos, M. R., Daughney, C. J., Jackson, B. M., and Morgenstern, U.: Regional-scale identification of groundwater-surface water interaction using hydrochemistry and multivariate statistical methods, Wairarapa Valley, New Zealand, Hydrol. Earth Syst. Sci. Discuss., 8, 6443-6487, doi:10.5194/hessd-8-6443-2011, 2011.

Guglielmi, Y. and Mudry, J.: Estimation of spatial and temporal variability of recharge fluxes to an alluvial aquifer in a fore land area by water chemistry and isotopes, Ground Water, 34, 1017-1023, 199.

Hawke, R., McConchie, J., and Trueman, T.: Wairarapa irrigation study: moisture availability as a result of the climate School of Earth Sciences Research Report, Victoria University of Wellington Wellington, 2000.

Hill, T. and Neal, C.: Spatial and temporal variation in $\mathrm{pH}$, alkalinity and conductivity in surface runoff and groundwater for the Upper River Severn catchment, Hydrol. Earth Syst. Sci., 1, 697-715, doi:10.5194/hess-1-697-1997, 1997.

Jagannadha Sarma, V. V., Prasad, N. V., and Prasad, R.: The effect of hydrogeology on varia-
HESSD

8, 10225-10273, 2011

\section{Investigation of groundwater-surface water interaction}

M. R. Guggenmos et al.

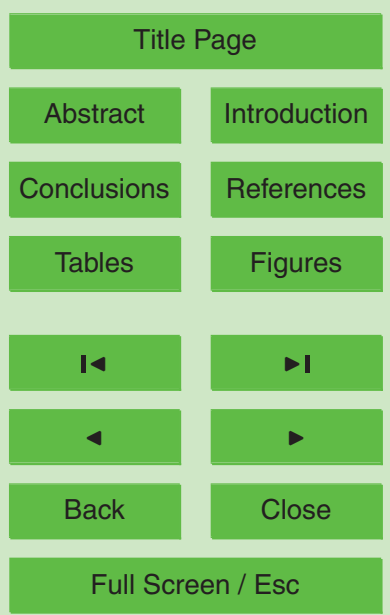

Printer-friendly Version

Interactive Discussion 
tions in electrical conductivity of groundwater fluctuations, J. Hydrol., 44, 81-87, 1979.

Jenkins, A., Norman, P. E., and Rodhe, A.: Hydrology, in: Biogeochemistry of small catchments: A tool for environmental research, edited by: Moldan, B. and Cerny, J., John Wiley \& Sons, Ltd, Chichester, 1994.

5 Kalbus, E., Reinstorf, F., and Schirmer, M.: Measuring methods for groundwater - surface water interactions: a review, Hydrol. Earth Syst. Sci., 10, 873-887, doi:10.5194/hess-10-873-2006, 2006.

Kamp, P. J. J.: Landforms of Wairarapa: A Geological Perspective, in: Landforms of New Zealand, edited by: Soons, J. M. and Selby, M. J., Longman Paul Ltd, Auckland, 1992.

Kirchner, J. W.: Getting the right answers for the right reasons: Linking measurements, analyses and models to advance the science of hydrology, Water Resour. Res., 42, W03S04, doi:10.1029/2005WR004362, 2006.

Kirchner, J. W., Feng, X., Neal, C., and Robson, A. J.: The fine structure of water-quality dynamics: the (high-frequency) wave of the future, Hydrol. Process., 18, 1353-1359, 2004.

Kumar, M., Ramanathan, A., and Keshari, A. K.: Understanding the extent of interactions between groundwater and surface water through major ion chemistry and multivariate statistical techniques, Hydrol. Process., 23, 297-310, 2009.

Laudon, $\mathrm{H}$. and Slaymaker, O.: Hydrograph separation using stable isotopes, silica and electrical conductivity: an alpine example, J. Hydrol., 201, 82-101, 1997.

20 Lu, X., Jin, M., van Genuchten, M. T., and Wang, B.: Groundwater recharge at five representative sites in the Hebei Plain, China, Ground Water, 49, 286-294, 2010.

McConchie, J.: From shaky beginnings, in: Dynamic Wellington: A contemporary synthesis and explanation of Wellington, edited by: McConchie, J., Winchester, D. R., and Willis, R., Institute of Geography: Victoria University of Wellington, Wellington, 2000.

Morgan, M. and Hughes, B.: Wellington, in: Groundwaters of New Zealand, edited by: Rosen, M. R. and White, P., NZ Hydrological Society, Wellington, 397-410, 2001.

O'Driscoll, M. A. and DeWalle, D. R.: Stream-air temperature relations to classify streamgroundwater interactions in a karst setting, central Pennsylvania, USA, J. Hydrol., 329, 140153, 2006.

30 Oxtobee, J. P. A. and Novakowski, K.: A field investigation of groundwater/surface water interaction in a fractured bedrock environment, J. Hydrol., 269, 169-193, 2002.

Rodgers, P., Soulsby, C., Petry, J., Malcolm, I., Gibbins, C., and Dunn, S.: Groundwater-surfacewater interactions in a braided river: a tracer based assessment, Hydrol. Process., 18, 1315-
HESSD

8, 10225-10273, 2011

\section{Investigation of groundwater-surface water interaction}

M. R. Guggenmos et al.

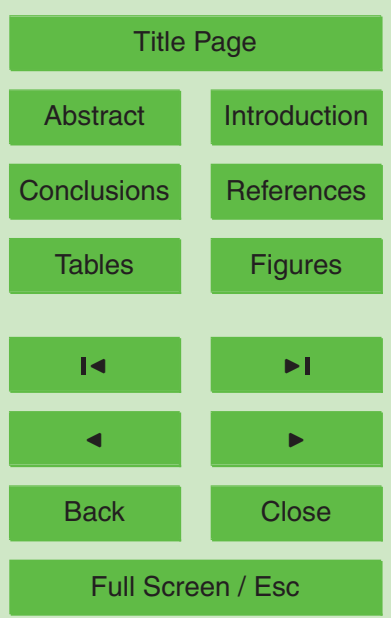

Printer-friendly Version

Interactive Discussion 
1332, 2004.

Rozemeijer, J. C. and Broers, H. P.: The groundwater contribution to surface water contamination in a region with intensive agricultural land use (Noord-Brabant, The Netherlands), Environ. Pollut., 148, 695-706, 2007.

5 Saffigna, P. G. and Keeney, D. R.: Nitrate and Chloride in Groundwater under irrigated agriculture in Central Wisconsin, Ground Water, 15, 170-177, 1977.

Scanlon, B. R.: Physical controls on Hydrochemical variability in the Inner Bluegrass Karst Region of Central Kentucky, Ground Water, 27, 639-646, 1989.

Schmalz, B., Springer, P., and Fohrer, N.: Interactions between near-surface groundwater and surface water in a drained riparian wetland, in: Groundwater-Surface Water Interaction: Process Understanding, Conceptualization and Modelling, edited by: Abesser, C., Wagener, T., and Nuetzmann, G., International Association of Hydrological Sciences, Oxford, 21-29, 2007.

Silliman, S. E. and Booth, D. F.: Analysis of timeseries measurements of sediment temperature 15 for identification of gaining vs. losing portions of Juday Creel, Indiana Journal of Hydrology, 146, 131-148, 1993.

Sophocleous, M.: Interactions between groundwater and surface water: the state of science, Hydrogeol. J., 10, 52-67, 2002.

Taylor, C. B., Wilson, D. D., Brown, L. J., Stewart, M. K., Burden, R. J., and Brailsford, G. W.: Sources and flow of North Canterbury Plains Groundwater, New Zealand, J. Hydrol., 106, 311-340, 1989.

Tetzlaff, D. and Soulsby, C.: Sources of baseflow in larger catchments - using tracers to develop a holistic understanding of runoff generation, J. Hydrol., 359, 297-302, 2008.

Whittemore, D. O., McGregor, K. M., and Marotz, G. A.: Effects of variations in recharge on groundwater quality, J. Hydrol., 106, 131-145, 1989.

Wollschläger, U., Ilmberger, J., Isenbeck-Scröter, M., Kreuzer, A.M., vo Rohden, C., Roth, K., and Schafer, W.: Coupling of groundwater and surface water at Lake Willersinnweiher: Groundwater modelling and tracer studies, Aquatic Science, 69, 417-431, 2007.

\section{HESSD}

8, 10225-10273, 2011

\section{Investigation of groundwater-surface water interaction}

M. R. Guggenmos et al.

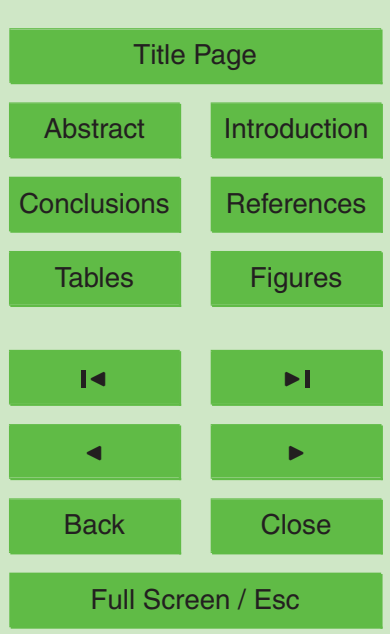

Printer-friendly Version

Interactive Discussion 


\section{HESSD}

8, 10225-10273, 2011

\section{Investigation of groundwater-surface water interaction}

Table 1. Catchment size and summer and winter discharge ranges from the Mangatarere stream at State Highway 2 and various input streams. "Summer discharge" denotes OctoberApril, while "Winter discharge" denotes May-September. Discharge ranges obtained by GWRC data 2008-2009.

\begin{tabular}{lrrr}
\hline Stream & $\begin{array}{r}\text { Catchment } \\
\text { size }\end{array}$ & $\begin{array}{r}\text { Summer } \\
\text { discharge } \\
\left(\mathrm{m}^{3} \mathrm{~s}^{-1}\right)\end{array}$ & $\begin{array}{r}\text { Winter } \\
\text { discharge } \\
\left(\mathrm{m}^{3} \mathrm{~s}^{-1}\right)\end{array}$ \\
\hline Enaki & $32 \mathrm{~km}^{2}$ & $0.4-0.33$ & $0.30-2.74$ \\
Kaipatangata & $23 \mathrm{~km}^{2}$ & $0.04-0.30$ & $0.17-1.77$ \\
Beef Creek & $30 \mathrm{~km}^{2}$ & $0.05-0.75$ & $0.65-6.4$ \\
Mangatarere total & $160 \mathrm{~km}^{2}$ & $0.36-2.69$ & $2.64-15.4$ \\
\hline
\end{tabular}

M. R. Guggenmos et al.

Title Page

Abstract

Introduction

Conclusions

References

Tables

Figures

14

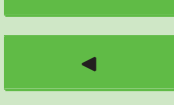

Back

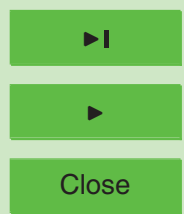

Full Screen / Esc

Printer-friendly Version

Interactive Discussion 


\section{HESSD}

8, 10225-10273, 2011

\section{Investigation of \\ groundwater-surface water interaction}

Table 2. Mean solute concentrations, pvH and Total Dissolved Solids (TDS) for the upstream and downstream surface and groundwater stations and precipitation, Mangatarere stream catchment, Wairarapa Valley, New Zealand, JD021-028. Number of observations $(n)$ and standard deviations (in parentheses) are also presented. All solute values are presented as mean $\mathrm{mgl}^{-1}$ concentrations. TDS column determined from the sum of main ions $\left(\mathrm{Ca}, \mathrm{HCO}_{3}^{-}, \mathrm{Cl}^{-}\right.$, $\mathrm{Mg}, \mathrm{K}, \mathrm{Na}$ and $\mathrm{SO}_{4}{ }^{2+}$ ).

\begin{tabular}{|c|c|c|c|c|c|c|c|c|c|c|c|c|c|c|c|c|}
\hline Location & $n$ & $\mathrm{pH}$ & TDS & $\mathrm{HCO}_{3}^{-}$ & $\mathrm{Cl}^{-}$ & $\mathrm{Ca}$ & $\mathrm{Mg}$ & $\mathrm{K}$ & $\mathrm{Na}$ & $\mathrm{SO}_{4}{ }^{2-}$ & As & $\mathrm{Fe}$ & $\mathrm{Mn}$ & $\mathrm{P}$ & $\mathrm{NO}_{3}^{-} \mathrm{N}$ & $\mathrm{NH}_{4}-\mathrm{N}$ \\
\hline $\begin{array}{l}\text { Up- } \\
\text { stream } \\
\text { SW }\end{array}$ & 15 & $\begin{array}{l}7.3 \\
(0.1)\end{array}$ & 49.9 & $\begin{array}{l}24.8 \\
(1.4)\end{array}$ & $\begin{array}{l}8.6 \\
(0.6)\end{array}$ & $\begin{array}{l}4.3 \\
(0.2)\end{array}$ & $\begin{array}{l}1.4 \\
(0.1)\end{array}$ & $\begin{array}{l}0.8 \\
(0.1)\end{array}$ & $\begin{array}{l}7.2 \\
(0.4)\end{array}$ & $\begin{array}{l}2.8 \\
(0.3)\end{array}$ & $\begin{array}{l}<0.001 \\
(0.000)\end{array}$ & $\begin{array}{l}0.044 \\
(0.029)\end{array}$ & $\begin{array}{l}0.002 \\
(0.001)\end{array}$ & $\begin{array}{l}0.006 \\
(0.001)\end{array}$ & $\begin{array}{l}0.04 \\
(0.02)\end{array}$ & $\begin{array}{l}0.010 \\
(0.001)\end{array}$ \\
\hline $\begin{array}{l}\text { Up- } \\
\text { stream } \\
\text { GW }\end{array}$ & 15 & $\begin{array}{l}7.2 \\
(0.2)\end{array}$ & 128.2 & $\begin{array}{l}72.6 \\
(5.0)\end{array}$ & $\begin{array}{l}11.9 \\
(0.3)\end{array}$ & $\begin{array}{l}12.27 \\
(1.2)\end{array}$ & $\begin{array}{l}5.7 \\
(0.4)\end{array}$ & $\begin{array}{l}1.2 \\
(0.11)\end{array}$ & $\begin{array}{l}14.8 \\
(1.0)\end{array}$ & $\begin{array}{l}9.7 \\
(0.6)\end{array}$ & $\begin{array}{l}<0.001 \\
(0.000)\end{array}$ & $\begin{array}{l}0.093 \\
(0.049)\end{array}$ & $\begin{array}{l}0.142 \\
(0.019)\end{array}$ & $\begin{array}{l}0.007 \\
(0.003)\end{array}$ & $\begin{array}{l}2.09 \\
(0.45)\end{array}$ & $\begin{array}{l}0.038 \\
(0.015)\end{array}$ \\
\hline $\begin{array}{l}\text { Down- } \\
\text { stream } \\
\text { SW }\end{array}$ & 15 & 7.2 & 65.7 & $\begin{array}{l}31.0 \\
(2.2)\end{array}$ & $\begin{array}{l}10.7 \\
(0.7)\end{array}$ & $\begin{array}{l}6.2 \\
(0.3)\end{array}$ & $\begin{array}{l}2.0 \\
0.2)\end{array}$ & $\begin{array}{l}1.3 \\
(0.1)\end{array}$ & $\begin{array}{l}8.7 \\
(0.6)\end{array}$ & $\begin{array}{l}5.8 \\
(0.6)\end{array}$ & $\begin{array}{l}<0.001 \\
(0.000)\end{array}$ & $\begin{array}{l}0.054 \\
(0.037)\end{array}$ & $\begin{array}{l}0.003 \\
(0.001)\end{array}$ & $\begin{array}{l}0.072 \\
(0.003)\end{array}$ & $\begin{array}{l}0.48 \\
(0.08)\end{array}$ & $\begin{array}{l}0.100 \\
(0.04)\end{array}$ \\
\hline $\begin{array}{l}\text { Down- } \\
\text { stream } \\
\text { GW }\end{array}$ & 3 & $\begin{array}{l}6.7 \\
(0.2)\end{array}$ & 145.8 & $\begin{array}{l}66.3 \\
(2.9)\end{array}$ & $\begin{array}{l}25.7 \\
(0.6)\end{array}$ & $\begin{array}{l}15.0 \\
(1.7)\end{array}$ & $\begin{array}{l}6.4 \\
(0.4)\end{array}$ & $\begin{array}{l}1.4 \\
(0.2)\end{array}$ & $\begin{array}{l}18.7 \\
(1.2)\end{array}$ & $\begin{array}{l}12.3 \\
(1.2)\end{array}$ & $\begin{array}{l}<0.001 \\
(0.000)\end{array}$ & $\begin{array}{l}3.400 \\
(2.307)\end{array}$ & $\begin{array}{l}0.036 \\
(0.019)\end{array}$ & $\begin{array}{l}0.069 \\
(0.031)\end{array}$ & $\begin{array}{l}2.60 \\
(0.52)\end{array}$ & $\begin{array}{l}0.095 \\
(0.09)\end{array}$ \\
\hline $\begin{array}{l}\text { Precipi- } \\
\text { tation }\end{array}$ & 2 & - & - & - & $<0.5$ & $<0.05$ & $<0.02$ & $<0.05$ & $\begin{array}{l}0.065 \\
(0.042)\end{array}$ & $<0.50$ & - & - & - & - & - & - \\
\hline
\end{tabular}

Dash (-) indicates analyte was not tested.

M. R. Guggenmos et al.

Title Page

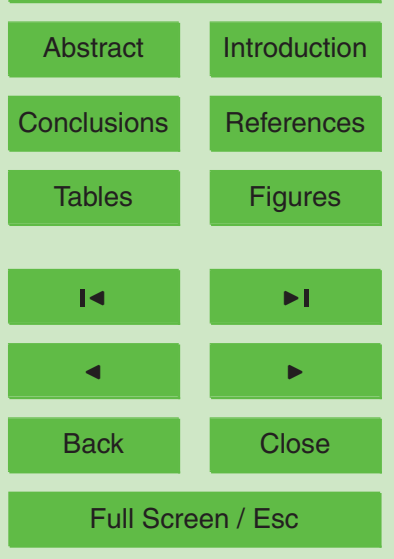

Printer-friendly Version

Interactive Discussion 
Table 3. Sample date, time, TDS, $\mathrm{Cl}^{-} / \mathrm{HCO}_{3}^{-}$and $\mathrm{Ca} / \mathrm{Na}$ ratios and water type for the upstream and downstream surface and groundwater hydrochemical samples, Mangatarere stream catchment, JD021-028.

\begin{tabular}{|c|c|c|c|c|c|}
\hline Location & Sample date \& time & TDS & $\mathrm{Cl} / \mathrm{HCO}_{3}$ & $\mathrm{Ca} / \mathrm{Na}$ & Water type \\
\hline \multirow[t]{15}{*}{ Downstream SW } & JD021 @ 11:00 & 67 & 2.82 & 0.74 & $\mathrm{Na}-\mathrm{Ca}-\mathrm{HCO}_{3}-\mathrm{Cl}$ \\
\hline & JD022 @ 12:00 & 70 & 3.00 & 0.70 & $\mathrm{Na}-\mathrm{Ca}-\mathrm{HCO}_{3}-\mathrm{Cl}$ \\
\hline & JD023 @ 12:00 & 56 & 2.83 & 0.77 & $\mathrm{Na}-\mathrm{Ca}-\mathrm{HCO}_{3}-\mathrm{Cl}$ \\
\hline & JD024 @ 12:00 & 58 & 2.78 & 0.73 & $\mathrm{Na}-\mathrm{Ca}-\mathrm{HCO}_{3}-\mathrm{Cl}$ \\
\hline & JD025 @ 12:00 & 64 & 3.10 & 0.75 & $\mathrm{Na}-\mathrm{Ca}-\mathrm{HCO}_{3}-\mathrm{Cl}$ \\
\hline & JD025 @ 15:00 & 63 & 3.00 & 0.70 & $\mathrm{Na}-\mathrm{Ca}-\mathrm{HCO}_{3}-\mathrm{Cl}$ \\
\hline & JD025 @ 18:00 & 66 & 2.73 & 0.73 & $\mathrm{Na}-\mathrm{Ca}-\mathrm{HCO}_{3}-\mathrm{Cl}$ \\
\hline & JD025 @ 21:00 & 67 & 2.82 & 0.70 & $\mathrm{Na}-\mathrm{Ca}-\mathrm{HCO}_{3}-\mathrm{Cl}$ \\
\hline & JD026@ 00:00 & 67 & 2.91 & 0.70 & $\mathrm{Na}-\mathrm{Ca}-\mathrm{HCO}_{3}-\mathrm{Cl}$ \\
\hline & JD026 @ 03:00 & 67 & 2.91 & 0.71 & $\mathrm{Na}-\mathrm{Ca}-\mathrm{HCO}_{3}-\mathrm{Cl}$ \\
\hline & JD026 @ 06:00 & 66 & 2.82 & 0.70 & $\mathrm{Na}-\mathrm{Ca}-\mathrm{HCO}_{3}-\mathrm{Cl}$ \\
\hline & JD026 @ 09:00 & 66 & 2.82 & 0.71 & $\mathrm{Na}-\mathrm{Ca}-\mathrm{HCO}_{3}-\mathrm{Cl}$ \\
\hline & JD026@12:00 & 66 & 2.91 & 0.73 & $\mathrm{Na}-\mathrm{Ca}-\mathrm{HCO}_{3}-\mathrm{Cl}$ \\
\hline & JD027 @ 12:00 & 69 & 3.00 & 0.70 & $\mathrm{Na}-\mathrm{Ca}-\mathrm{HCO}_{3}-\mathrm{Cl}$ \\
\hline & JD028@12:00 & 73 & 2.92 & 0.72 & $\mathrm{Na}-\mathrm{Ca}-\mathrm{HCO}_{3}-\mathrm{Cl}$ \\
\hline \multirow[t]{3}{*}{ Downstream GW } & JD021 @ 11:30 & 141 & 2.52 & 0.78 & $\mathrm{Na}-\mathrm{Ca}-\mathrm{Mg}-\mathrm{HCO}_{3}-\mathrm{Cl}$ \\
\hline & JD023@11:30 & 153 & 2.62 & 0.85 & $\mathrm{Na}-\mathrm{Ca}-\mathrm{Mg}-\mathrm{HCO}_{3}-\mathrm{Cl}$ \\
\hline & JD028@11:30 & 145 & 2.62 & 0.78 & $\mathrm{Na}-\mathrm{Ca}-\mathrm{Mg}-\mathrm{HCO}_{3}-\mathrm{Cl}$ \\
\hline \multirow[t]{15}{*}{ Upstream SW } & JD021@ 12:30 & 50 & 2.55 & 0.58 & $\mathrm{Na}-\mathrm{Ca}-\mathrm{HCO}_{3}-\mathrm{Cl}$ \\
\hline & JD022 @ 12:30 & 54 & 2.60 & 0.56 & $\mathrm{Na}-\mathrm{Ca}-\mathrm{HCO}_{3}-\mathrm{Cl}$ \\
\hline & JD023 @ 12:30 & 44 & 2.84 & 0.64 & $\mathrm{Na}-\mathrm{Ca}-\mathrm{HCO}_{3}-\mathrm{Cl}$ \\
\hline & JD024 @ 12:30 & 40 & 2.95 & 0.59 & $\mathrm{Na}-\mathrm{Ca}-\mathrm{HCO}_{3}-\mathrm{Cl}$ \\
\hline & JD025 @ 12:30 & 48 & 2.89 & 0.61 & $\mathrm{Na}-\mathrm{Ca}-\mathrm{HCO}_{3}-\mathrm{Cl}$ \\
\hline & JD025 @ 15:30 & 48 & 2.89 & 0.62 & $\mathrm{Na}-\mathrm{Ca}-\mathrm{HCO}_{3}-\mathrm{Cl}$ \\
\hline & JD025@18:30 & 51 & 3.10 & 0.61 & $\mathrm{Na}-\mathrm{Ca}-\mathrm{HCO}_{3}-\mathrm{Cl}$ \\
\hline & JD025 @ 21:30 & 50 & 2.94 & 0.62 & $\mathrm{Na}-\mathrm{Ca}-\mathrm{HCO}_{3}-\mathrm{Cl}$ \\
\hline & JD026 @ 00:30 & 51 & 2.84 & 0.62 & $\mathrm{Na}-\mathrm{Ca}-\mathrm{HCO}_{3}-\mathrm{Cl}$ \\
\hline & JD026 @ 03:30 & 50 & 3.01 & 0.64 & $\mathrm{Na}-\mathrm{Ca}-\mathrm{HCO}_{3}-\mathrm{Cl}$ \\
\hline & JD026 @ 06:30 & 51 & 3.02 & 0.64 & $\mathrm{Na}-\mathrm{Ca}-\mathrm{HCO}_{3}-\mathrm{Cl}$ \\
\hline & JD026 @ 09:30 & 51 & 3.02 & 0.63 & $\mathrm{Na}-\mathrm{Ca}-\mathrm{HCO}_{3}-\mathrm{Cl}$ \\
\hline & JD026 @ 12:30 & 50 & 2.98 & 0.61 & $\mathrm{Na}-\mathrm{Ca}-\mathrm{HCO}_{3}-\mathrm{Cl}$ \\
\hline & JD027 @ 12:30 & 51 & 2.95 & 0.55 & $\mathrm{Na}-\mathrm{Ca}-\mathrm{HCO}_{3}-\mathrm{Cl}$ \\
\hline & JD028 @ 12:30 & 52 & 2.86 & 0.56 & $\mathrm{Na}-\mathrm{Ca}-\mathrm{HCO}_{3}-\mathrm{Cl}$ \\
\hline
\end{tabular}

HESSD

8, 10225-10273, 2011

\section{Investigation of groundwater-surface water interaction}

M. R. Guggenmos et al.

\section{Title Page}

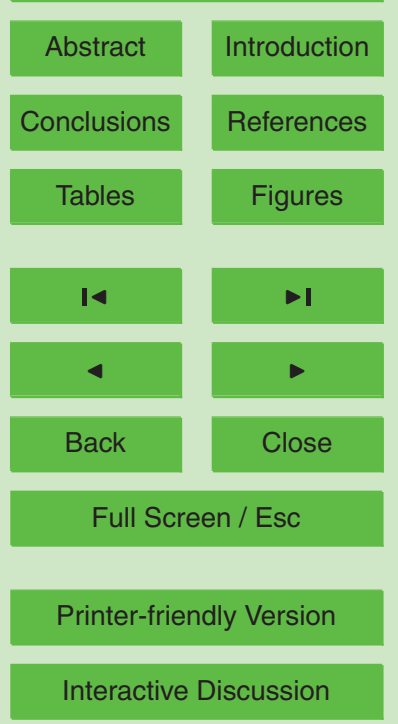




\section{HESSD}

8, 10225-10273, 2011

\section{Investigation of groundwater-surface water interaction}

\begin{tabular}{|c|c|c|c|c|c|}
\hline Location & Sample date \& time & TDS & $\mathrm{Cl} / \mathrm{HCO}_{3}$ & $\mathrm{Ca} / \mathrm{Na}$ & Water type \\
\hline Upstream GW & $\begin{array}{l}\text { JD021 @ 13:00 } \\
\text { JD022 @ 13:00 } \\
\text { JD023 @ 13:00 } \\
\text { JD024 @ 13:00 } \\
\text { JD025 @ 13:00 } \\
\text { JD025 @ 16:00 } \\
\text { JD025 @ 19:00 } \\
\text { JD025 @ 22:00 } \\
\text { JD026 @ 01:00 } \\
\text { JD026 @ } 04: 00 \\
\text { JD026 @ 07:00 } \\
\text { JD026 @ 10:00 } \\
\text { JD026 @ 13:00 } \\
\text { JD027 @ 13:00 } \\
\text { JD028 @ 13:00 }\end{array}$ & $\begin{array}{l}140 \\
142 \\
132 \\
126 \\
130 \\
132 \\
132 \\
129 \\
126 \\
130 \\
130 \\
126 \\
119 \\
117 \\
115\end{array}$ & $\begin{array}{l}6.67 \\
6.83 \\
6.33 \\
6.00 \\
6.17 \\
6.17 \\
6.08 \\
6.00 \\
5.83 \\
6.17 \\
6.25 \\
6.00 \\
5.42 \\
5.42 \\
5.91\end{array}$ & $\begin{array}{l}0.88 \\
0.76 \\
0.87 \\
0.86 \\
0.80 \\
0.93 \\
0.88 \\
0.87 \\
0.80 \\
0.80 \\
0.86 \\
0.79 \\
0.79 \\
0.79 \\
0.77\end{array}$ & $\begin{array}{l}\mathrm{Ca}-\mathrm{Na}-\mathrm{Mg}-\mathrm{HCO}_{3} \\
\mathrm{Na}-\mathrm{Ca}-\mathrm{Mg}-\mathrm{HCO}_{3} \\
\mathrm{Na}-\mathrm{Ca}-\mathrm{Mg}-\mathrm{HCO}_{3} \\
\mathrm{Na}-\mathrm{Ca}-\mathrm{Mg}-\mathrm{HCO}_{3} \\
\mathrm{Na}-\mathrm{Ca}-\mathrm{Mg}-\mathrm{HCO}_{3} \\
\mathrm{Ca}-\mathrm{Na}-\mathrm{Mg}-\mathrm{HCO}_{3} \\
\mathrm{Ca}-\mathrm{Na}-\mathrm{Mg}-\mathrm{HCO}_{3} \\
\mathrm{Na}-\mathrm{Ca}-\mathrm{Mg}-\mathrm{HCO}_{3} \\
\mathrm{Na}-\mathrm{Ca}-\mathrm{Mg}-\mathrm{HCO}_{3} \\
\mathrm{Na}-\mathrm{Ca}-\mathrm{Mg}-\mathrm{HCO}_{3} \\
\mathrm{Na}-\mathrm{Ca}-\mathrm{Mg}-\mathrm{HCO}_{3} \\
\mathrm{Na}-\mathrm{Ca}-\mathrm{Mg}-\mathrm{HCO}_{3}-\mathrm{Cl} \\
\mathrm{Na}-\mathrm{Ca}-\mathrm{Mg}-\mathrm{HCO}_{3}-\mathrm{Cl} \\
\mathrm{Na}-\mathrm{Ca}-\mathrm{Mg}-\mathrm{HCO}_{3}-\mathrm{Cl} \\
\mathrm{Na}-\mathrm{Ca}-\mathrm{Mg}-\mathrm{HCO}_{3}-\mathrm{Cl}\end{array}$ \\
\hline
\end{tabular}

M. R. Guggenmos et al.

Title Page

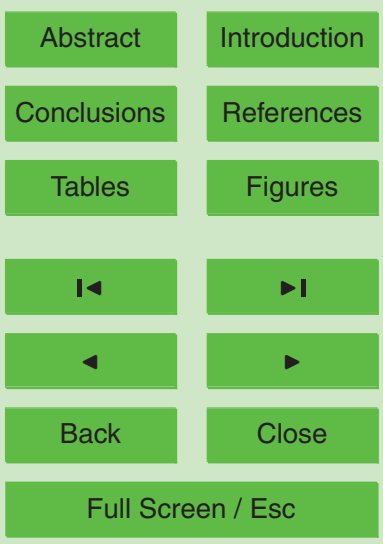

Printer-friendly Version

Interactive Discussion 


\section{HESSD}

8, 10225-10273, 2011

\section{Investigation of groundwater-surface water interaction}

Table A1. Stage and discharge rating data from the Mangatarere gauging station at Gorge. Data provided by GWRC.

\begin{tabular}{ll}
\hline Stage $(\mathrm{m})$ & Discharge $\left(\mathrm{m} \mathrm{s}^{-1}\right)$ \\
\hline 0.378 & 0.121 \\
0.412 & 0.229 \\
0.435 & 0.303 \\
0.478 & 0.516 \\
0.561 & 1.146 \\
0.635 & 2.189 \\
0.723 & 4.134 \\
0.894 & 9.05 \\
1.468 & 30.535 \\
1.981 & 66 \\
3.5 & 220 \\
\hline
\end{tabular}

M. R. Guggenmos et al.

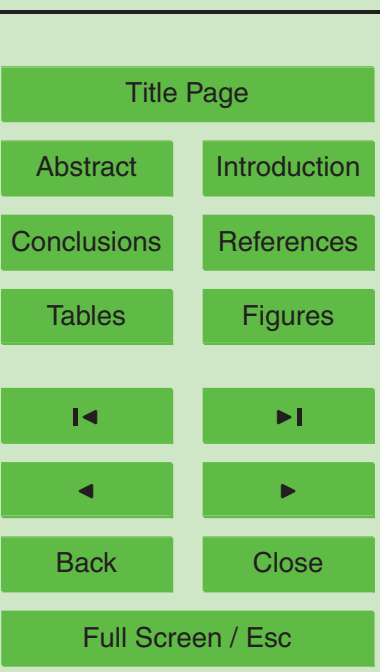

Printer-friendly Version

Interactive Discussion 
Table A2. Stage and discharge $(Q)$ rating data from the Mangatarere at State Highway 2 (SH2), also known as the downstream gauging station. Data provided by GWRC.

\begin{tabular}{|c|c|c|c|c|c|c|c|}
\hline Stage $(m)$ & $Q\left(\mathrm{~m}^{3} \mathrm{~s}^{-1}\right)$ & Stage $(m)$ & $Q\left(\mathrm{~m}^{3} \mathrm{~s}^{-1}\right)$ & Stage $(m)$ & $Q\left(\mathrm{~m}^{3} \mathrm{~s}^{-1}\right)$ & Stage $(m)$ & $Q\left(\mathrm{~m}^{3} \mathrm{~s}^{-1}\right)$ \\
\hline 0.4 & 0.008 & 0.89 & 9.94 & 1.38 & 32.2 & 1.87 & 64.6 \\
\hline 0.41 & 0.07 & 0.9 & 10.3 & 1.39 & 32.7 & 1.88 & 65.3 \\
\hline 0.42 & 0.134 & 0.91 & 10.6 & 1.4 & 33.3 & 1.89 & 66.1 \\
\hline 0.43 & 0.199 & 0.92 & 11 & 1.41 & 33.8 & 1.9 & 66.9 \\
\hline 0.44 & 0.265 & 0.93 & 11.4 & 1.42 & 34.4 & 1.91 & 67 \\
\hline 0.45 & 0.335 & 0.94 & 11.7 & 1.43 & 35 & 1.92 & 68.5 \\
\hline 0.46 & 0.407 & 0.95 & 12.1 & 1.44 & 35.6 & 1.93 & 69.2 \\
\hline 0.47 & 0.481 & 0.96 & 12.5 & 1.45 & 36.2 & 1.94 & 70 \\
\hline 0.48 & 0.556 & 0.97 & 12.9 & 1.46 & 36.8 & 1.95 & 70.8 \\
\hline 0.49 & 0.633 & 0.98 & 13.3 & 1.47 & 37.3 & 1.96 & 71.6 \\
\hline 0.5 & 0.711 & 0.99 & 13.6 & 1.48 & 37.9 & 1.97 & 72.4 \\
\hline 0.51 & 0.791 & 1 & 14 & 1.49 & 38.5 & 1.98 & 73.3 \\
\hline 0.52 & 0.88 & 1.01 & 14.4 & 1.5 & 39.2 & 1.99 & 74.1 \\
\hline 0.53 & 0.98 & 1.02 & 14.8 & 1.51 & 39.8 & 2 & 74.9 \\
\hline 0.54 & 1.09 & 1.03 & 15.2 & 1.52 & 40.4 & 2.01 & 75.7 \\
\hline 0.55 & 1.2 & 1.04 & 15.7 & 1.53 & 41 & 2.02 & 76.5 \\
\hline 0.56 & 1.31 & 1.05 & 16.1 & 1.54 & 41.6 & 2.03 & 77.4 \\
\hline 0.57 & 1.43 & 1.06 & 16.5 & 1.55 & 42.2 & 2.04 & 78.2 \\
\hline 0.58 & 1.57 & 1.07 & 16.9 & 1.56 & 42.9 & 2.05 & 79 \\
\hline 0.59 & 1.71 & 1.08 & 17.3 & 1.57 & 43.5 & 2.06 & 79.9 \\
\hline 0.6 & 1.86 & 1.09 & 17.8 & 1.58 & 44.3 & 2.07 & 80.7 \\
\hline 0.61 & 2.02 & 1.1 & 18.2 & 1.59 & 44.8 & 2.08 & 81.6 \\
\hline 0.62 & 2.18 & 1.11 & 18.7 & 1.6 & 45.5 & 2.09 & 82.5 \\
\hline 0.63 & 2.35 & 1.12 & 19.1 & 1.61 & 46.1 & 2.1 & 83.3 \\
\hline 0.64 & 2.53 & 1.13 & 19.5 & 1.62 & 46.8 & 2.11 & 84.2 \\
\hline 0.65 & 2.76 & 1.14 & 20 & 1.63 & 47.4 & 2.12 & 85 \\
\hline 0.66 & 3 & 1.15 & 20.5 & 1.64 & 48.1 & 2.13 & 85.9 \\
\hline 0.67 & 3.25 & 1.16 & 20.9 & 1.65 & 48.8 & 2.14 & 86.8 \\
\hline 0.68 & 3.52 & 1.17 & 21.4 & 1.66 & 49.4 & 2.15 & 87.7 \\
\hline 0.69 & 3.8 & 1.18 & 21.9 & 1.67 & 50.1 & 2.16 & 88.6 \\
\hline 0.7 & 4.07 & 1.19 & 22.3 & 1.68 & 50.8 & 2.17 & 89.5 \\
\hline 0.71 & 4.34 & 1.20 & 22.8 & 1.69 & 51.5 & 2.18 & 90.4 \\
\hline 0.72 & 4.62 & 1.21 & 23.3 & 1.7 & 52.2 & 2.19 & 91.3 \\
\hline 0.73 & 4.89 & 1.22 & 23.8 & 1.71 & 52.9 & 2.2 & 92.2 \\
\hline 0.74 & 5.19 & 1.23 & 24.3 & 1.72 & 53.6 & 2.21 & 93.1 \\
\hline 0.75 & 5.47 & 1.24 & 25.8 & 1.73 & 54.3 & 2.22 & 94 \\
\hline 0.76 & 5.76 & 1.25 & 25.3 & 1.74 & 55 & 2.23 & 94.9 \\
\hline 0.77 & 6.05 & 1.26 & 25.8 & 1.75 & 55.7 & 2.24 & 95.8 \\
\hline 0.78 & 6.35 & 1.27 & 26.3 & 1.76 & 56.4 & 2.25 & 96.7 \\
\hline 0.79 & 6.66 & 1.28 & 26.8 & 1.77 & 57.1 & 2.26 & 97.7 \\
\hline 0.8 & 6.97 & 1.29 & 27.3 & 1.78 & 57.9 & 2.27 & 98.6 \\
\hline 0.81 & 7.28 & 1.30 & 27.8 & 1.79 & 58.6 & 2.28 & 99.5 \\
\hline 0.82 & 7.6 & 1.31 & 28.4 & 1.8 & 59.3 & 2.29 & 100 \\
\hline 0.83 & 7.92 & 1.32 & 28.9 & 1.81 & 60.1 & 2.3 & 101 \\
\hline 0.84 & 8.25 & 1.33 & 29.4 & 1.82 & 60.8 & 2.31 & 102 \\
\hline 0.85 & 8.58 & 1.34 & 30 & 1.83 & 61.5 & 2.32 & 103 \\
\hline 0.86 & 8.91 & 1.35 & 30.5 & 1.84 & 62.3 & 2.33 & 104 \\
\hline 0.87 & 9.25 & 1.36 & 31.1 & 1.85 & 63.1 & 2.34 & 105 \\
\hline 0.88 & 9.59 & 1.37 & 31.6 & 1.86 & 63.8 & 2.35 & 106 \\
\hline 0.89 & 9.94 & 0.89 & 9.94 & 1.38 & 32.2 & 1.87 & 64.6 \\
\hline 0.4 & 0.008 & 0.9 & 10.3 & 1.39 & 32.7 & 1.88 & 65.3 \\
\hline 0.41 & 0.07 & 0.91 & 10.6 & 1.4 & 33.3 & 1.89 & 66.1 \\
\hline
\end{tabular}

\section{HESSD}

8, 10225-10273, 2011

\section{Investigation of groundwater-surface water interaction}

M. R. Guggenmos et al.

Title Page

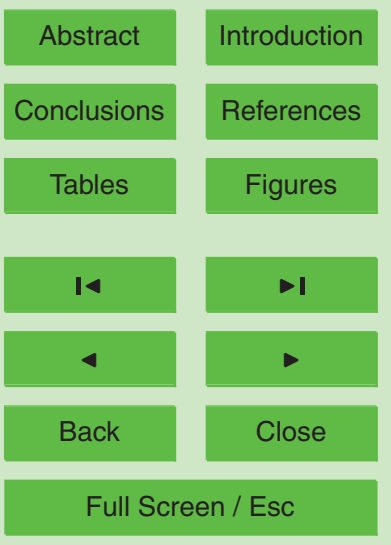

Printer-friendly Version

Interactive Discussion 


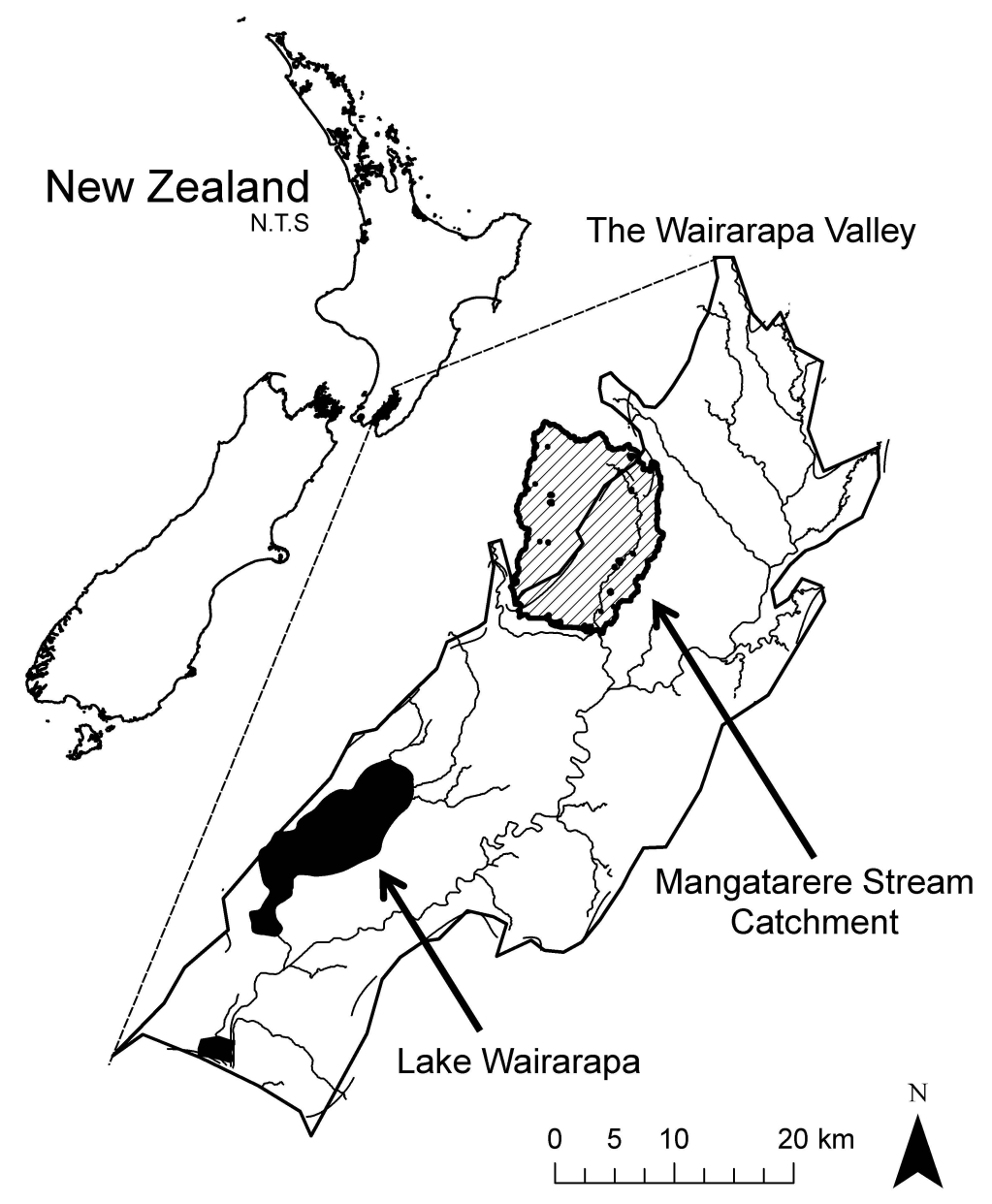

HESSD

8, 10225-10273, 2011

\section{Investigation of groundwater-surface water interaction}

M. R. Guggenmos et al.

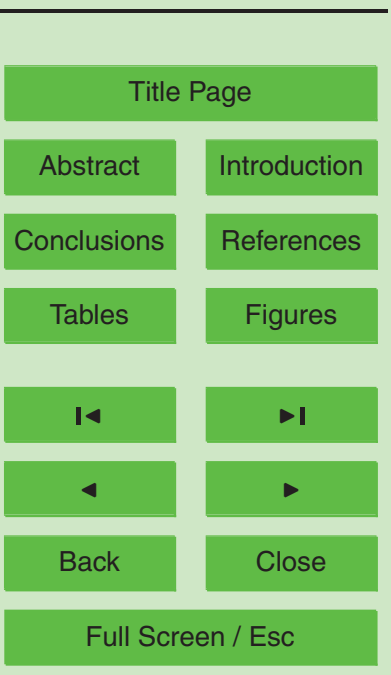

Printer-friendly Version

Fig. 1. Location of Mangatarere Stream catchment and study area within the Wairarapa Valley, North Island, New Zealand. Note: map of New Zealand is Not To Scale (N.T.S). 


\section{HESSD}

8, 10225-10273, 2011

\section{Investigation of groundwater-surface water interaction}

M. R. Guggenmos et al.

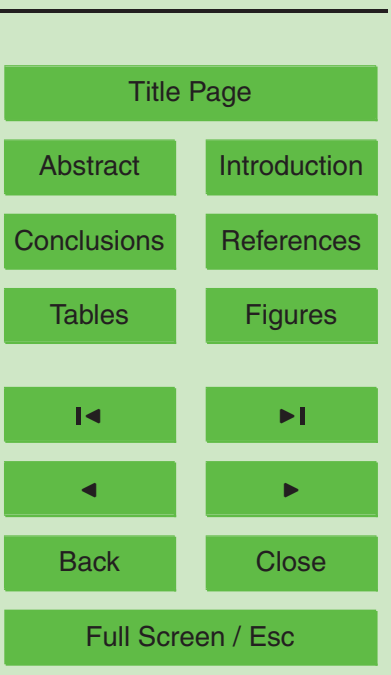

Printer-friendly Version

Interactive Discussion 


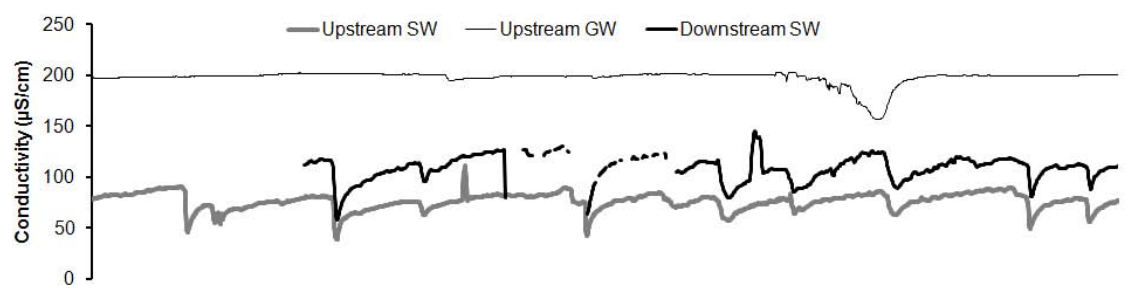

HESSD

8, 10225-10273, 2011

\section{Investigation of groundwater-surface water interaction}

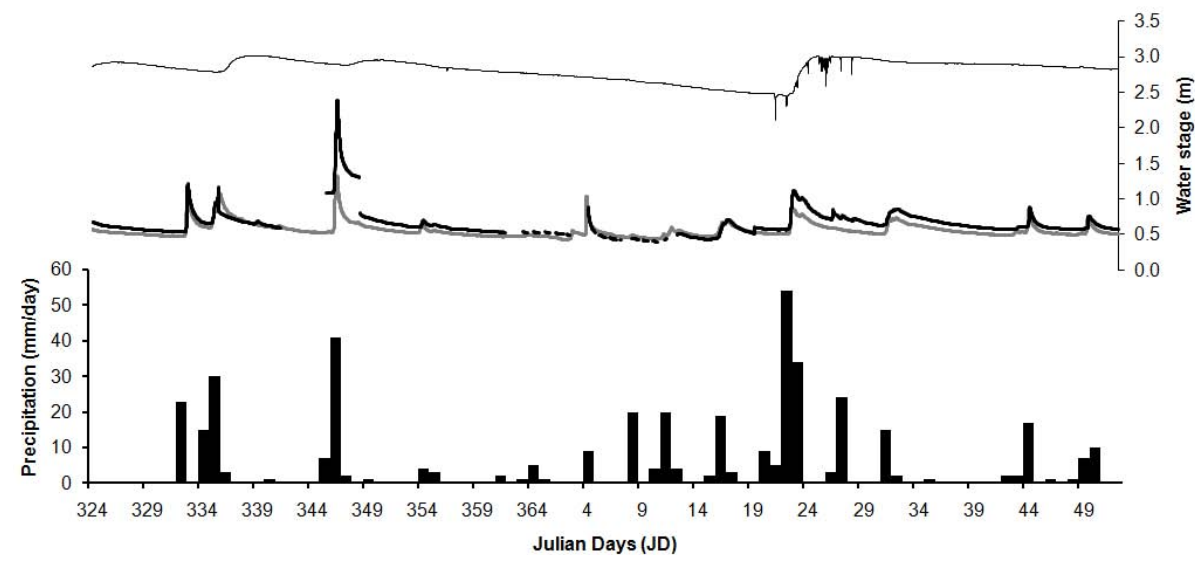

M. R. Guggenmos et al.

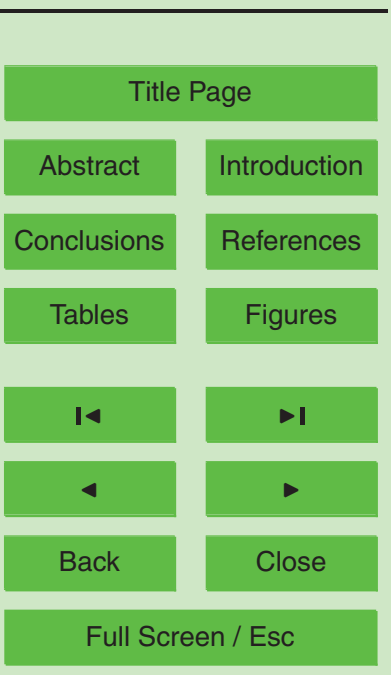

Fig. 3. Time series data for total daily precipitation, water stage and electrical conductivity for the upstream surface (SW) and groundwater (GW) gauging stations and downstream surface water (SW) gauging station, Mangatarere stream, Wairarapa Valley, New Zealand, JD324-051. Water stage and conductivity data are presented at $15 \mathrm{~min}$ intervals while precipitation is total $\mathrm{mm}$ per day.

Printer-friendly Version

Interactive Discussion 


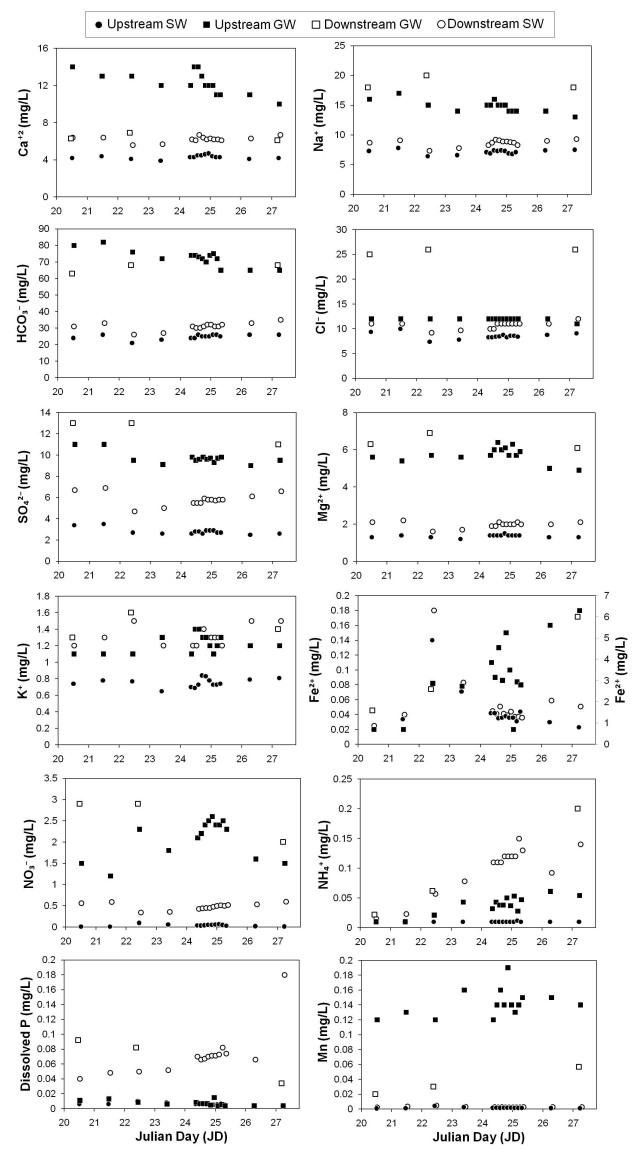

Fig. 4. Temporal variations in major ions, nutrients and trace elements $\mathrm{Fe}$ and $\mathrm{Mn}$ at the upstream and downstream surface water and groundwater gauging stations JD021-028, Mangatarere stream catchment. All y-axis scales are in units of $\mathrm{mgl}^{-1}$. Note: the Fe concentration for the downstream groundwater station is presented on the secondary $y$-axis.

\section{HESSD}

8, 10225-10273, 2011

\section{Investigation of groundwater-surface water interaction}

M. R. Guggenmos et al.

\section{Title Page}

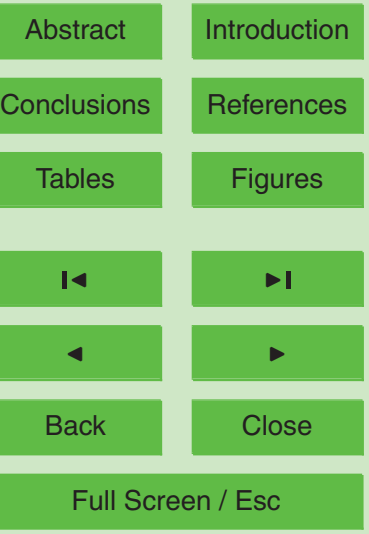

Printer-friendly Version

Interactive Discussion 


\section{HESSD}

8, 10225-10273, 2011
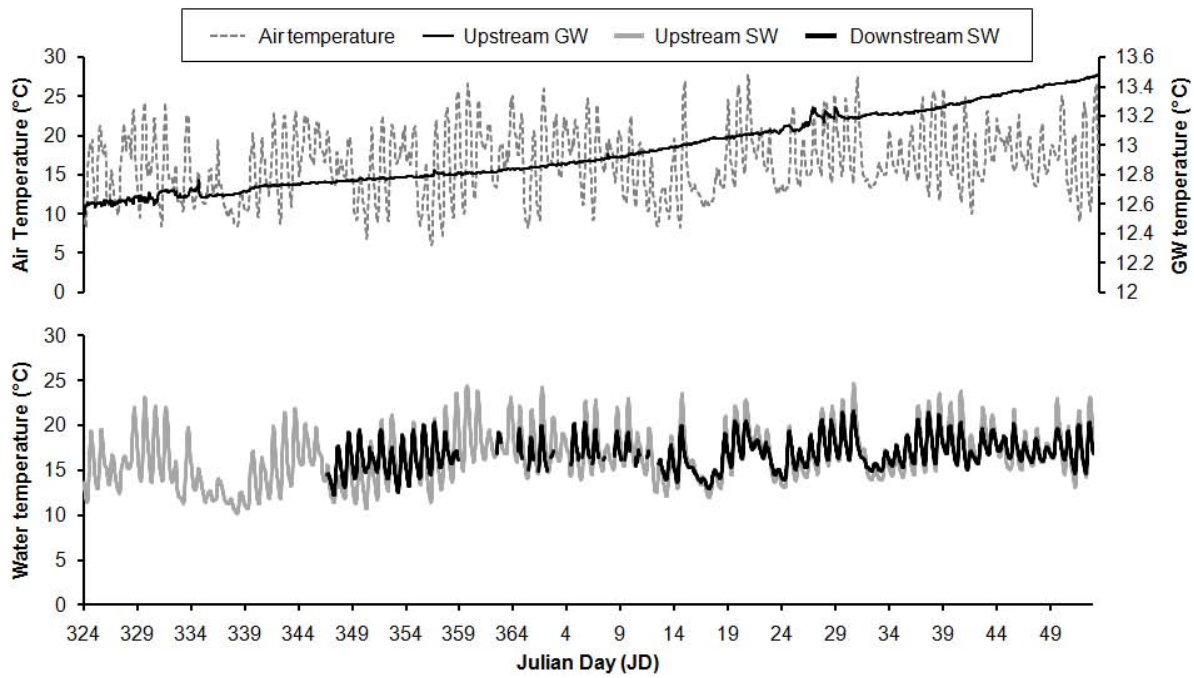

Fig. 5. Temporal variations in air temperature, upstream surface (SW) and groundwater (GW) temperature and downstream surface water temperature, Mangatarere stream catchment, JD324-051.

\section{Investigation of groundwater-surface water interaction}

M. R. Guggenmos et al.

Title Page

Abstract

Introduction

Conclusions

References

Tables

Figures

I

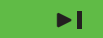

4

Back

Close

\section{Full Screen / Esc}

Printer-friendly Version

Interactive Discussion 


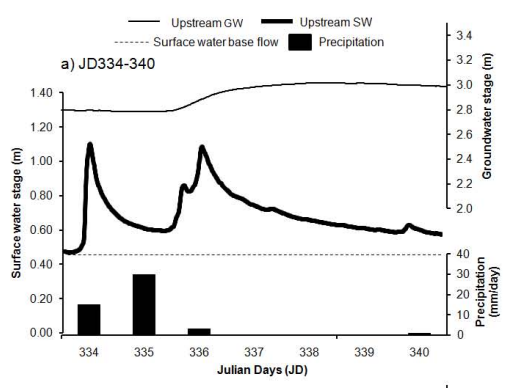

HESSD

8, 10225-10273, 2011

\section{Investigation of groundwater-surface water interaction}

M. R. Guggenmos et al.
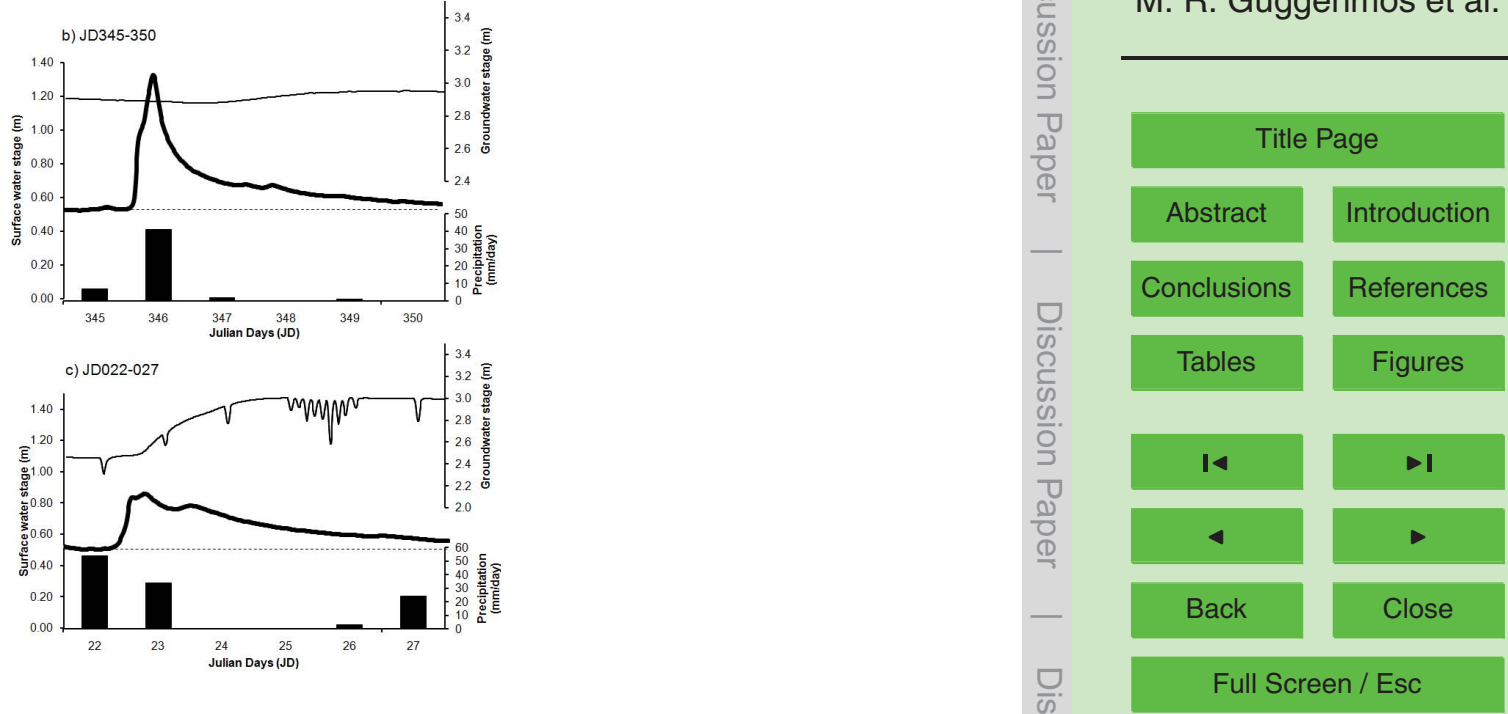

Fig. 6. Storm hydrographs from selected upstream surface water events and concurrent groundwater stage response JD334-340 (a), 345-350 (b) and JD022-027 (c). Dotted horizontal line denotes approximate base flow conditions prior to the surface water stage response. Stage data are presented at $15 \mathrm{~min}$ intervals, while precipitation data are presented as a daily total $\left(\mathrm{mm}\right.$ day $\left.^{-1}\right)$.

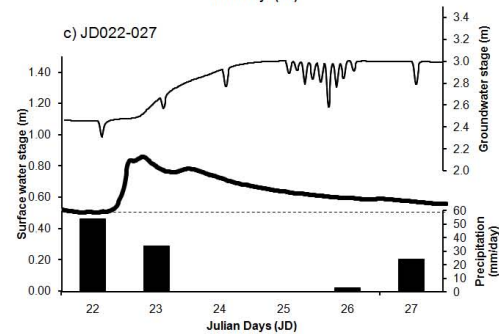

Printer-friendly Version

Interactive Discussion 


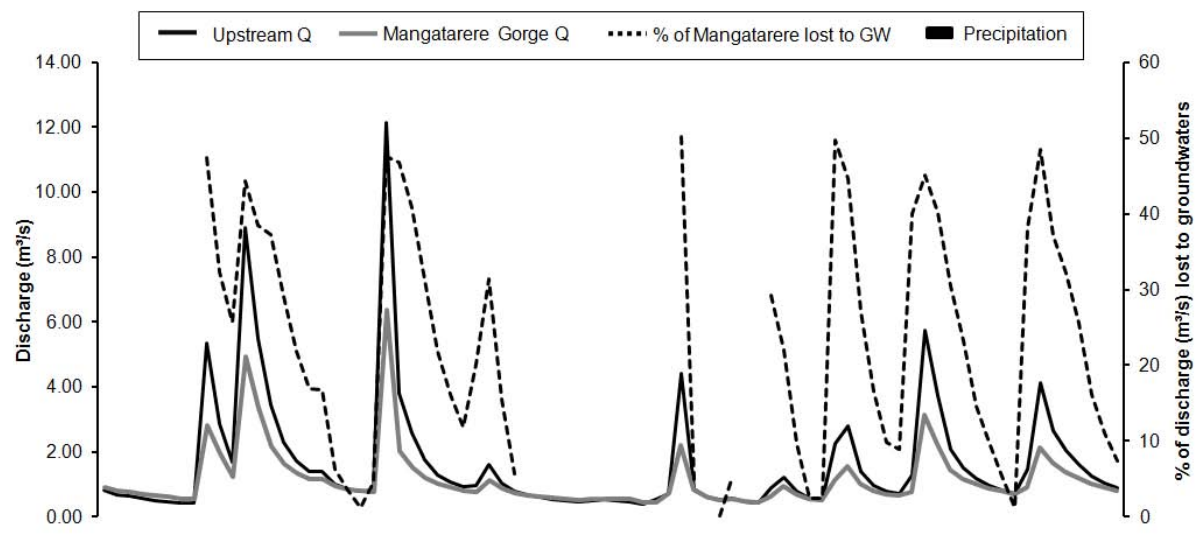

HESSD

8, 10225-10273, 2011

\section{Investigation of groundwater-surface water interaction}

M. R. Guggenmos et al.

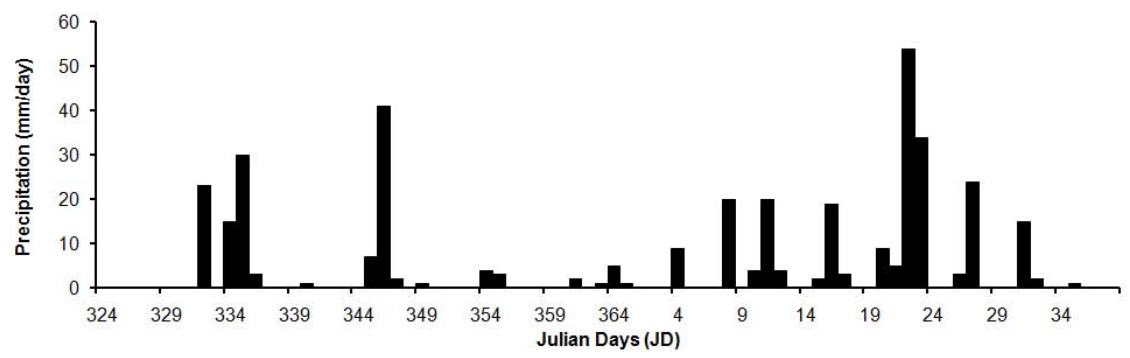

Fig. 7. GWRC Mangatarere at Gorge monitoring station and the upstream surface water station average daily discharge measurements JD324-039. The difference in discharge between the Mangatarere at Gorge site and upstream station is deemed lost to underlying groundwater. Precipitation and the \% of Mangatarere at Gorges discharge lost to groundwater system are also shown.

Title Page

Abstract

Introduction

Conclusions

References

Tables

Figures

14

4

Back

Close

\section{Full Screen / Esc}

Printer-friendly Version

Interactive Discussion 


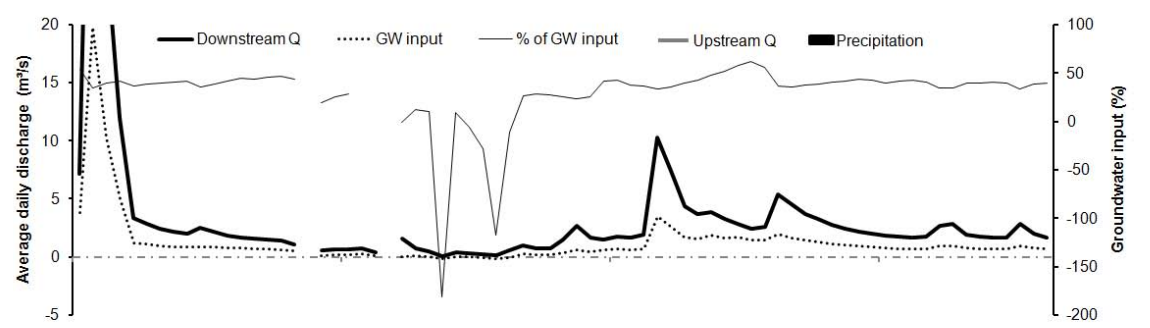

HESSD

8, 10225-10273, 2011

\section{Investigation of groundwater-surface water interaction}

M. R. Guggenmos et al.
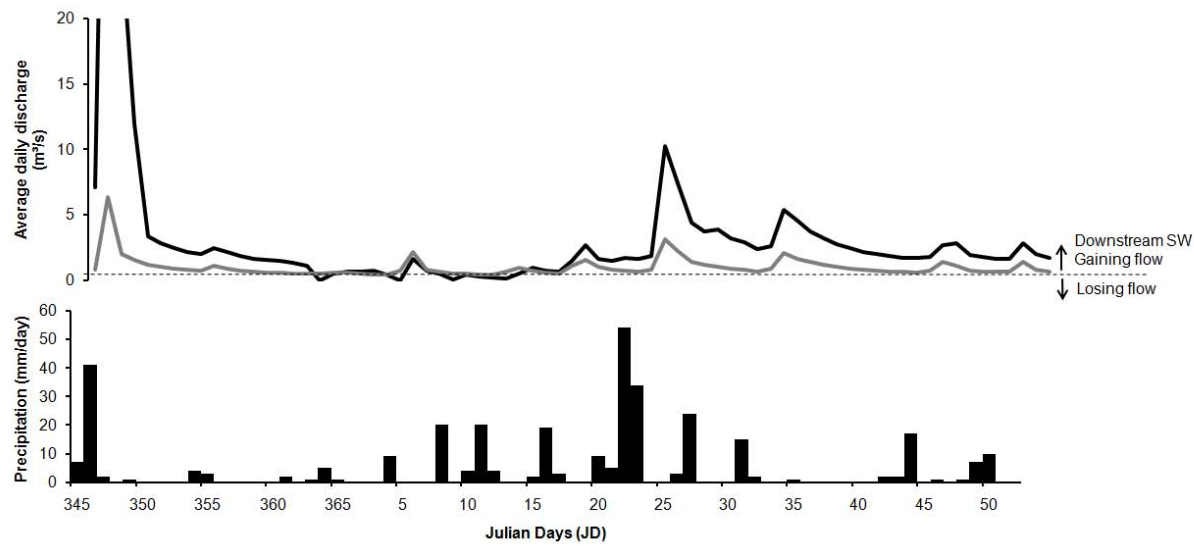

Fig. 8. Average daily upstream and downstream surface water discharge $(Q)$ and groundwater input to downstream surface water gauging station. Precipitation and the percentage of downstream base flow provided by groundwater sources are also presented. Note: average daily discharge (primary y-axis) has been fixed at $20 \mathrm{~m}^{3} \mathrm{~s}^{-1}$ to allow for the interpretation of small changes in discharge despite the high flow event on JD345 peaking at $55 \mathrm{~m}^{3} \mathrm{~s}^{-1}$.

Title Page

Abstract Introduction

Conclusions References

Tables

Figures

14

4

Back

Close

Full Screen / Esc

Printer-friendly Version

Interactive Discussion 


\section{HESSD}

8, 10225-10273, 2011

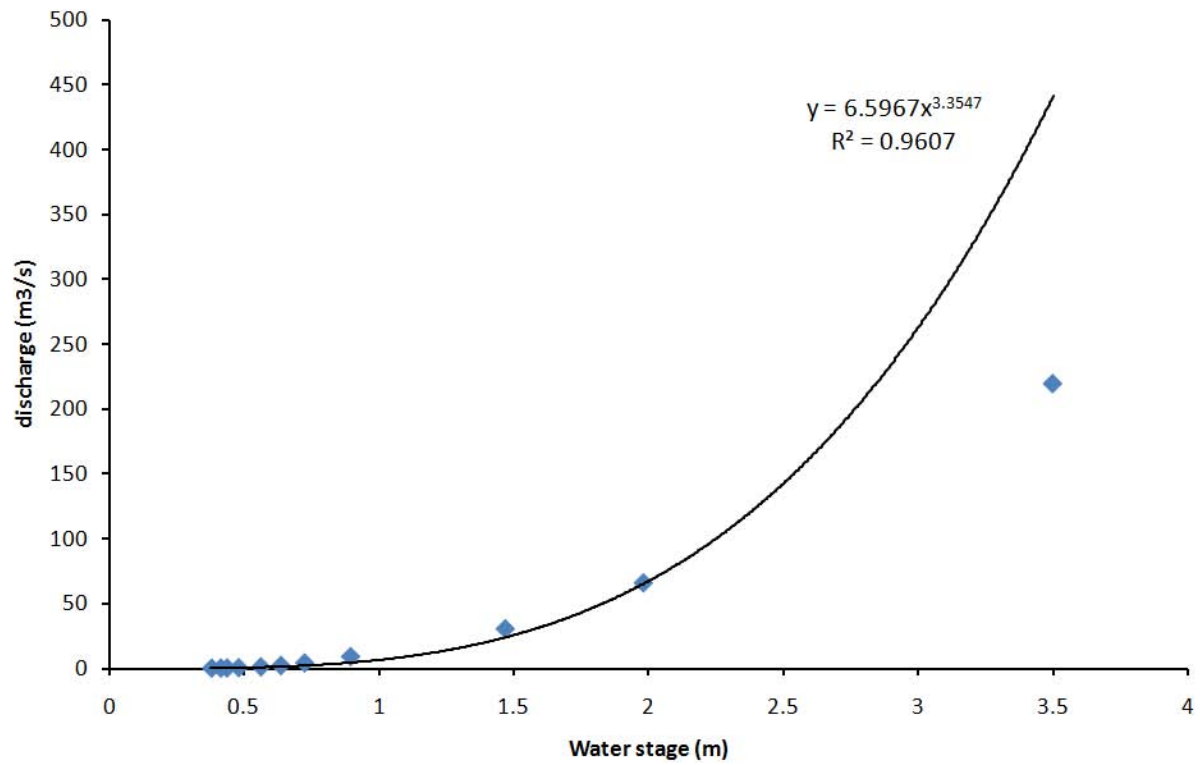

Fig. A1. Fitted power relationship between water stage and corresponding discharge measurements at the Mangatarere at Gorge gauging station. Discharge measurements lie close to the fitted curve as indicated by a high coefficient of determination $\left(R^{2}=0.96\right)$. However, this relationship breaks down in the higher discharge range $\left(>150 \mathrm{~m}^{3} \mathrm{~s}^{-1}\right)$. This is no considered an issue, as this research does not deal with stage and therefore discharge values in this range. Stage values for this research fall within $0.4-2.5 \mathrm{~m}$.

\section{Investigation of groundwater-surface water interaction}

M. R. Guggenmos et al.

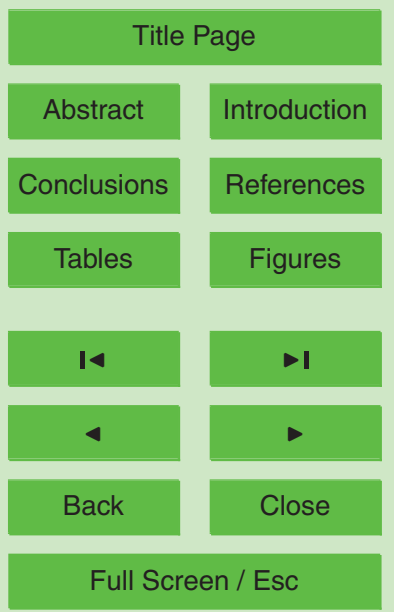

Printer-friendly Version

Interactive Discussion 


\section{HESSD}

8, 10225-10273, 2011

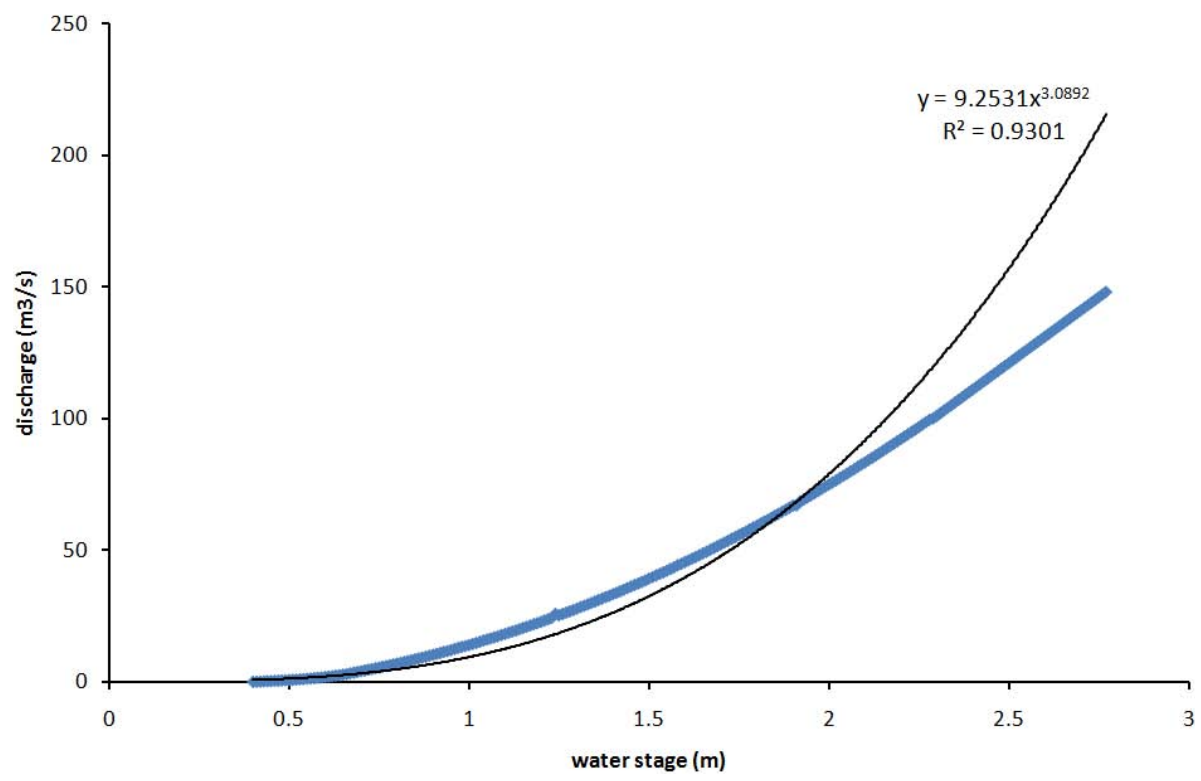

\section{Investigation of groundwater-surface water interaction}

M. R. Guggenmos et al.

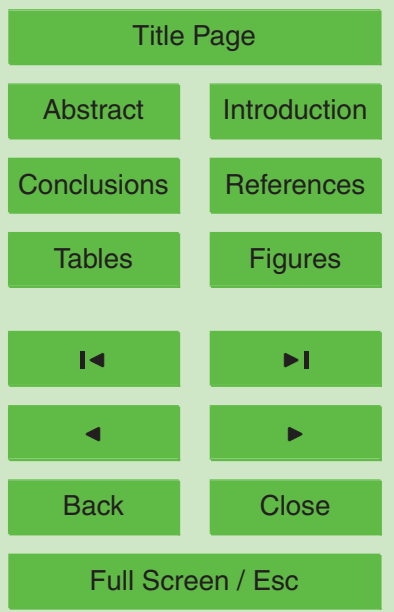

Fig. A2. Fitted power relationship between water stage and corresponding discharge measurements at the Mangatarere stream State Highway $2(\mathrm{SH} 2)$ gauging station. Also known as the downstream gauging station. Discharge measurements lie close to the fitted curve as indicated by a high coefficient of determination $\left(R^{2}=0.96\right)$. However, this relationship breaks down in the higher discharge range $\left(>50 \mathrm{~m}^{3} \mathrm{~s}^{-1}\right)$. This is no considered an issue, as this research does not deal with discharge values in this range. Stage values for this research fall within $0.4-2.5 \mathrm{~m}$.

Printer-friendly Version

Interactive Discussion 